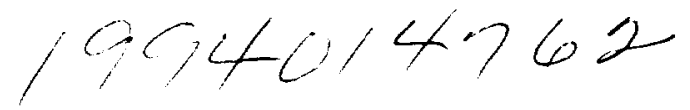

GLOBAL BIOGEOCHEMICAL CYCLES, VOL. 6, NO. 3, PAGES 271-291, SEPTEMBER 1992

\section{FACTORS THAT CONTROL THE STABLE CARBON ISOTOPIC COMPOSITION OF METHANE PRODUCED IN AN ANOXIC MARINE SEDIMENT}

\author{
M. J. Alperin \\ Curriculum in Marine Sciences, University of North \\ Carolina, Chapel Hill
}

N. E. Blair

Department of Marine, Earth, and Atmospheric

Sciences, North Carolina State University, Raleigh

D. B. Albert, T. M. Hoehler, and C. S. Martens

Curriculum in Marine Sciences, University of North Carolina, Chapel Hill

\begin{abstract}
The carbon isotopic composition of methane produced in anoxic marine sediment is controlled by four factors: (1) the pathway of methane formation, (2) the isotopic composition of the methanogenic precursors, (3) the isotope fractionation factors for methane production, and (4) the isotope fractionation associated with methane oxidation. The importance of each factor was evaluated by monitoring stable carbon isotope ratios in methane produced by a sediment microcosm. Methane did not accumulate during the initial 42-day period when sediment contained sulfate, indicating little methane production from "noncompetitive" substrates. Following sulfate depletion, methane accumulation proceeded in three distinct phases. First, $\mathrm{CO}_{2}$ reduction was the dominant methanogenic pathway and the isotopic composition of the methane produced ranged from -80 to $-94 \%$. The acetate concentration increased during this phase, suggesting that acetoclastic methanogenic bacteria were unable to keep pace with acetate production. Second, acetate fermentation became the dominant methanogenic pathway as bacteria responded to elevated acetate concentrations. The methane produced during this phase was progressively enriched in ${ }^{13} \mathrm{C}$, reaching a
\end{abstract}

Copyright 1992

by the American Geophysical Union.

Paper number 92GB01650.

0886-6236/92/92GB-01651\$10.00 maximum $\delta^{13} \mathrm{C}$ value of $-42 \%$. Third, the acetate pool experienced a precipitous decline from $>5 \mathrm{mM}$ to $<20 \mu \mathrm{M}$ and methane production was again dominated by $\mathrm{CO}_{2}$ reduction. The $\delta^{13} \mathrm{C}$ of methane produced during this final phase ranged from -46 to $-58 \%$. Methane oxidation concurrent with methane production was detected throughout the period of methane accumulation, at rates equivalent to 1 to $8 \%$ of the gross methane production rate. Thus methane oxidation was too slow to have significantly modified the isotopic signature of methane. A comparison of microcosm and field data suggests that similar microbial interactions may control seasonal variability in the isotopic composition of methane emitted from undisturbed Cape Lookout Bight sediment.

\section{INTRODUCTION}

Recent estimates place the current global methane flux to the atmosphere at $543 \pm 95 \times 10^{12} \mathrm{~g} \mathrm{CH}_{4} \mathrm{yr}^{-1}$ [Cicerone and Oremland, 1988]. A relatively high level of precision $( \pm 17 \%)$ is possible because the global methane flux is calculated from three wellcharacterized parameters: the size of the atmospheric methane reservoir, the rate of change in atmospheric methane concentration, and the average residence time for atmospheric methane. Accurate estimates of reservoir size and rate of change are provided by concentration time series data from permanent stations throughout the world [Blake and Rowland, 


\section{PRECEOINLi PAGE BLANK NOT FRMEU}

1988]. Likewise, the residence time for methane is tightly constrained by atmospheric models of the hydroxyl radical field (calibrated with methyl chloroform distributions) and laboratory measurements of the rate coefficient for the methanehydroxyl reaction [Prinn et al., 1987; Vaghjiani and Ravishankara, 1991; Taylor et al., 1991; Fung et al., 1991].

The contribution of individual sources to the total methane flux is much more difficult to constrain. The vast number and widespread geographic distribution of significant methane sources means that detailed studies of emission rates are limited to a relatively small number of representative systems. The precision of source strength estimates based on direct flux measurements is limited by spatial and temporal variability and uncertainty in the areal distribution of ecosystem types. The uncertainty of the global methane flux calculated by summing individual source terms is about $\pm 50 \%$ [Tyler, 1991].

Quantitative knowledge of individual source strengths is of critical importance because atmospheric methane concentrations have more than doubled during the past 300 years [Pearman, 1986]. Since methane is a radiatively active trace gas, an increase in the atmospheric methane reservoir could alter the Earth's energy budget and contribute to global-scale climate change [Cicerone and Oremland, 1988]. In addition, methane serves as a sink for the hydroxyl radical and therefore plays an important role in regulating the oxidizing power of the atmosphere [Cicerone and Oremland, 1988]. Accurate source strength estimates are necessary to understand the underlying causes of increasing atmospheric inventories and to evaluate the efficacy of different mitigation strategies.

The isotopic composition of carbon in the methane molecule serves as a natural tracer of source. Methane produced during biomass combustion is enriched in ${ }^{13} \mathrm{C}$ relative to that produced by methanogenic bacteria [Stevens and Engelkemeir, 1988]. Fossil methane (from natural gas pipelines, coal mining activities, clathrate decomposition, and peat remineralization) can be distinguished on the basis of its low ${ }^{14} \mathrm{C}$ content [Wahlen et al., 1989]. The isotopic composition of atmospheric methane can provide a global-scale estimate of the contribution of bacterial, biomass burning, and fossil sources to the global methane budget [Quay et al., $1991]$.

The accuracy of source strength estimates based on isotopic constraints is limited by variability in the isotopic composition of methane produced by individual sources. For example, $\delta^{13} \mathrm{C}$ values of methane emitted from a particular ecosystem (such as a temperate wetland, Arctic tundra, or rice paddy) can vary by as much as 20 to $30 \%$ [Quay et al., 1988; Tyler et al., 1988; Chanton and Martens, 1988]. The factors that contribute to this variability are not well understood.

One important factor in controlling the stable carbon isotopic composition of bacterial methane is the mechanism of methane formation. Acetate fermentation and $\mathrm{CO}_{2}$ reduction are thought to be the . dominant methane production pathways in nature [Oremland, 1988]. However, methanogenic bacteria are known to produce methane from alternative compounds such as formate, methanol, methylated amines, and methylated sulfur compounds [Oremland, 1988]. These compounds serve as important methane precursors in some environments [Strayer and Tiedje, 1978; Oremland et al., 1982; King et al., 1983; King, 1988], but their widespread significance remains a matter of debate.

The isotopic composition of methane produced by a particular pathway depends on the $\delta^{13} \mathrm{C}$ of the methane precursor and the isotope fractionation associated with the production process (i.e., the kinetic isotope effect). Therefore variations in $\delta^{13} \mathrm{C}^{-} \mathrm{CH}_{4}$ are controlled by the relative contribution of different methane production pathways, the isotopic composition of the methane precursors, and the kinetic isotope effect for each pathway. In addition, aerobic and anaerobic methane oxidation can alter the isotopic composition of the residual methane reservoir [King et al., 1989; Alperin et al., 1988].

Most field-based studies designed to characterize the isotopic composition of methane emitted from specific sources have not conducted the process-level research necessary to understand the factors that control $\delta^{13} \mathrm{C}_{-} \mathrm{CH}_{4}$ variability. In this study, we monitored the $\delta^{13} \mathrm{C}$ of methane produced by a laboratory microcosm containing anoxic marine sediment from Cape Lookout Bight, North Carolina. We concurrently measured methane production rates from $\mathrm{CO}_{2}$ and acetate, methane oxidation rates, $\delta^{13} \mathrm{C}-\Sigma \mathrm{CO}_{2}$, and a suite of key indicators of microbial processes. We observed large variations over time in the $\delta^{13} \mathrm{C}$ of methane produced by the microcosm. These variations can be attributed both to shifts in the relative importance of $\mathrm{CO}_{2}$ reduction and acetate fermentation, as well as changes in the isotopic composition of the methane precursors. The variability in $\delta^{13} \mathrm{C}$ - 
$\mathrm{CH}_{4}$ can be understood in terms of syntrophic and competitive interactions between the microorganisms involved in organic matter remineralization. A comparison of microcosm and field data suggests that similar microbial interactions may control seasonal variability in the isotopic composition of methane emitted from Cape Lookout Bight sediment.

\section{METHODS}

\section{Study Site and Sediment Sampling}

Sediment was collected from Cape Lookout Bight, a shallow $(10 \mathrm{~m})$ barrier island lagoon located $70 \mathrm{~km}$ southwest of Cape Hatteras, North Carolina. Organic carbon deposition at this site $(165 \pm 20 \mathrm{~mol}$ $\left.\mathrm{m}^{-2} \mathrm{yr}^{-1}\right)$ is among the highest reported for a coastal marine environment [Martens et al., 1992]. Sediment oxygen penetration is restricted to several hundred microns despite an air-saturated water column mixed by strong tidal currents. Sediment metabolism is dominated by microbial sulfate reduction and methane production, with methanogenesis accounting for about $30 \%$ of the annual integrated organic matter remineralization [Martens and Klump, 1984]. Metabolic rates exhibit strong seasonality driven by annual temperature changes of $>20^{\circ} \mathrm{C}$ [Klump and Martens, 1989]. Sulfate concentration profiles are modulated by seasonal variations in sulfate reduction rates; the vertical extent of the sulfate reduction zone oscillates from $>30 \mathrm{~cm}$ in the winter to $<10 \mathrm{~cm}$ in the summer [Crill and Martens, 1987]. Methane production rates are highest immediately below the sulfate reduction zone [Crill and Martens, 1986] and sediments are methanesaturated below this horizon. During the summer, methane bubbles form below $10 \mathrm{~cm}$ and low tide ebullition occurs in response to reduced hydrostatic pressure [Martens and Klump, 1980]. The $\delta^{13} \mathrm{C}$ of methane contained in these bubbles exhibits seasonal variations of $\sim 10 \%$ [Martens et al., 1986; Burke et al., 1987]. Sediment accumulation rates at this site are approximately $10 \mathrm{~cm} \mathrm{yr}^{-1}$ [Chanton et al., 1983; Canuel et al., 1990].

Sediment samples used in this study were collected in July 1990 when sulfate reduction and methane production rates were at their annual maximum. Cores were collected by SCUBA diver in $22 \mathrm{~cm} \times 13 \mathrm{~cm}$ diameter Plexiglass tubes. The tubes were gently inserted into the sediment and capped on top and bottom before being carefully withdrawn.
The cores were kept in the dark at in situ temperature $\left(26.5^{\circ} \mathrm{C}\right)$ during transport to the laboratory.

\section{Incubation Vessel}

A large capacity syringe (hereafter referred to as the "magnum syringe") capable of long-term headspace-free incubations was constructed for this study (Figure 1). The vessel was designed as a syringe to allow for intermittent sample withdrawal without introducing a headspace. The presence of a headspace would significantly alter concentrations of dissolved methane and $\Sigma \mathrm{CO}_{2}$.

The syringe barrel was fabricated from 4-inch $(10.16 \mathrm{~cm})$ ID Kimax Beaded Process Pipe with a 10-mm bore stopcock (Teflon plug) welded to one end. The piston was constructed of solid polyvinyl chloride (PVC) machined to provide a slide-fit within the syringe barrel. A thin Teflon plate was secured to the bottom of the piston to prevent contact between sediment and PVC. Attempts at making a direct O-ring seal between the piston and the barrel failed due to variability in the inner diameter of the glass

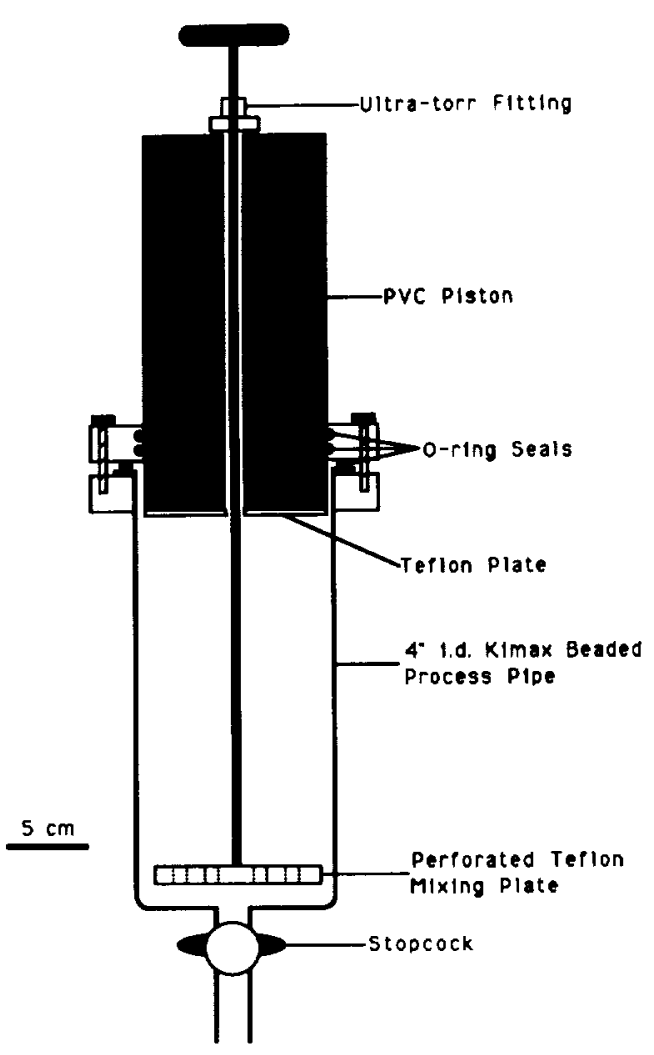

Fig. 1. Magnum syringe for incubating $2 \mathrm{~L}$ sediment under headspace-free, anoxic conditions. 
pipe. Therefore the piston was sealed to the barrel by means of a custom fabricated coupling that provided an O-ring seal to the barrel flange and a double $\mathrm{O}$-ring seal around the piston. Sediment within the magnum syringe could be homogenized without air contact by churning with a perforated Teflon mixing plate connected to a Teflon rod that passed through a slightly oversized hole bored through the center of the piston. The mixing rod was sealed to the top of the piston with an Ultra-torr fitting (Cajon Vacuum Products) that provided a gas-tight seal while allowing for axial movement.

The magnum syringe was filled with sediment from the 0 to $3 \mathrm{~cm}$ depth interval. Six cores were pooled to give a total sediment volume of $\sim 2 \mathrm{~L}$. The piston was positioned in such a way as to exclude gas pockets and fastened in place by securing the coupling. The magnum syringe was sampled at weekly intervals by displacing $120 \mathrm{~mL}$ of sediment into two $60-\mathrm{mL}$ catheter-tip plastic syringes that fit snugly in the arm of the stopcock. A large chain clamp immobilized the piston between sampling intervals. The sediment was homogenized prior to each sampling by churning sediment through the mixing plate. The magnum syringe was incubated in the dark at $22 \pm 1^{\circ} \mathrm{C}$.

\section{Concentration Measurements}

Sulfate, acetate, and $\Sigma \mathrm{CO}_{2}$ concentrations were determined on interstitial water extracted from whole sediment by centrifugation. Care was taken to prevent sediment and interstitial water from contacting air. Sediment was transferred to an argon-flushed 30-mL centrifuge tube and spun at $6000 \mathrm{G}$ for $15 \mathrm{~min}$. The centrifuge tube was filled to the top to minimize loss of gaseous $\mathrm{CO}_{2}$ into the headspace volume. Following centrifugation, supernatant from just above the solid-liquid interface was pipetted using a long stainless steel needle fixed to a $5-\mathrm{mL}$ glass syringe. The interstitial water was passed through a $0.45-\mu \mathrm{m}$ syringe filter; the first milliliter of filtrate was discarded.

Sulfate concentrations were determined using a Dionex 2010i ion chromatograph. In order to minimize sulfide oxidation in the sample, $1.0-\mathrm{mL}$ interstitial water was filtered directly into an argonflushed vial containing $100-\mu \mathrm{L} 10 \%(\mathrm{v} / \mathrm{v}) \mathrm{HCl}$ and stripped of volatile sulfur compounds by bubbling with $\mathrm{O}_{2}$-free argon. The samples were diluted 1:10 with distilled water and passed thru an ONGUARD$\mathrm{Ag}$ pretreatment cartridge (Dionex Corporation) to remove chloride. The large quantity of chloride in interstitial water $(\sim 600 \mathrm{mM})$ interferes with low-level $(<1 \mathrm{mM})$ sulfate determinations; after chloride removal the detection limit for sulfate was $5 \mu \mathrm{M}$.

Acetate concentrations were determined by HPLC using precolumn derivatization with 2-nitrophenylhydrazine [Albert et al., 1992]. The derivatives were prepared directly in the pore water and separated by a C8 reversed phase column with buffered, ion-pairing solvent. The detection limit for this method is $0.5 \mu \mathrm{M}$; the precision is typically $\pm 5 \%$.

Interstitial water for $\mathrm{\Sigma CO}_{2}$ analysis was stored in 3.5-mL Pyrex screw-cap vials filled to just below the rim and capped with Teflon-faced silicone septa. Loss of $\mathrm{CO}_{2}$ into the gas phase was prevented by displacing the headspace with a 4-mm Pyrex rod inserted through a hole in the septum. The $\mathrm{\Sigma CO}_{2}$ concentrations were determined using the inorganic carbon channel of a Shimadzu TOC-5000 total carbon analyzer. Samples $(25 \mu \mathrm{L})$ were injected directly into a gas stripping chamber containing $25 \%(\% / v) \mathrm{H}_{3} \mathrm{PO}_{4}$. The $\mathrm{CO}_{2}$ released upon acidification was quantified by a nondispersive infrared detector.

Whole sediment methane concentrations were measured by a headspace equilibration technique [Alperin and Reeburgh, 1985]. Whole sediment concentrations include methane dissolved in the pore water as well as methane bubbles trapped in the sediment. Sediment $(2.5 \mathrm{~mL})$ was transferred to a tared $30-\mathrm{mL}$ serum vial containing $3-\mathrm{mL} 0.1 \mathrm{~N}$ $\mathrm{NaOH}$, sealed with a silicone stopper, and thoroughly vortex-mixed to disperse the sediment and equilibrate the gas and aqueous phase. An aliquot of the headspace was analyzed for methane by a Shimadzu Mini-2 gas chromatograph equipped with flame ionization detector. Standards were prepared by injecting pure methane into sealed $30-\mathrm{mL}$ serum vials containing 3-mL $0.1 \mathrm{~N} \mathrm{NaOH}$ and $2.5-\mathrm{mL}$ distilled water. Samples and standards were kept at the same temperature and had equal volumes of aqueous phase and headspace, so corrections for the quantity of dissolved methane were not necessary. Whole sediment methane concentrations were converted to pore water units by dividing by sediment porosity.

\section{Rate Measurements}

Sulfate reduction [Albert et al., 1992], methane production from acetate [Crill and Martens, 1986], 
methane production from $\mathrm{CO}_{2}$ [Crill and Martens, 1986], and methane oxidation [Alperin and Reeburgh, 1985] rates were determined by previously described radiotracer techniques. Briefly, whole sediment was transferred to gas-tight $2.5-\mathrm{mL}$ glass incubation syringes and injected with microliter quantities of radiotracer $\left({ }^{35} \mathrm{SO}_{4}{ }^{2-},\left[\mathrm{U}-{ }^{14} \mathrm{C}\right]\right.$ acetate, $\left[{ }^{14} \mathrm{C}\right]-\mathrm{HCO}_{3}{ }^{-}$, or ${ }^{14} \mathrm{CH}_{4}$ ). The samples were incubated at $22 \pm 1^{\circ} \mathrm{C}$ for a time interval sufficient for 1 to $10 \%$ of the tracer pool to turnover. The incubation time was generally 24 hours, except samples injected with $\left[\mathrm{U}-{ }^{14} \mathrm{C}\right]$ acetate which had incubation times ranging from $10 \mathrm{~min}$ to 27 hours. At two times (93 and 107 days), the samples amended with $\left[\mathrm{U}-{ }^{14} \mathrm{C}\right]$ acetate were incubated sufficiently long that $40-60 \%$ of the tracer turned over. Methane production rates from acetate at these two times are considered to be underestimated.

Sediment samples assayed for sulfate reduction rate were "killed" by freezing the incubation syringes. For other rate measurements, the incubation was terminated by extruding the sediment into serum vials containing $\mathrm{NaOH}$ solution. The serum vials were quickly sealed with butyl-rubber or silicone stoppers and stored frozen and upside-down (to retard gas loss) until analysis. Collection and quantification of radioisotopes was according to published procedures (references given above). The rates were calculated from the following equation:

Rate $=[\mathrm{C}] \frac{\mathrm{a} \alpha}{\mathrm{A} t}$, where $[C]$ is reactant concentration (i.e., sulfate, acetate, $\Sigma \mathrm{CO}_{2}$, or methane), a and $\mathrm{A}$ are activities of recovered product and added reactant, respectively, $\alpha$ is the fractionation factor for the tracer isotope $\left({ }^{14} \mathrm{C}\right.$ or $\left.{ }^{35} \mathrm{~S}\right)$ relative to the dominant natural isotope $\left({ }^{12} \mathrm{C}\right.$ or $\left.{ }^{32} \mathrm{~S}\right)$, and $\mathrm{t}$ is the incubation time. The isotope fractionation factor was taken to be 1.12 for methane production from $\mathrm{CO}_{2}$ [Blair et al., 1992], 1.06 for methane production from acetate [Blair and Carter, 1992], 1.02 for methane oxidation [Alperin et al., 1988], and 1.045 for sulfate reduction [Jørgensen, 1978]. Note that isotope discrimination for ${ }^{14} \mathrm{C}$ is twice that for ${ }^{13} \mathrm{C}$ [Stern and Vogel, 1971].

\section{Stable Isotope Measurements}

The $\delta^{13} \mathrm{C}-\Sigma \mathrm{CO}_{2}$ analyses were done on $1.0-\mathrm{mL}$ aliquots of filtered interstitial water stored in $3-\mathrm{mL}$ serum vials capped with silicone septa. Samples

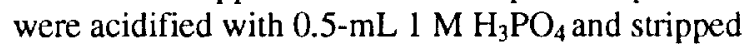
with helium into a gas purification line [Schaff et al.,
1992]. Air and $\mathrm{CO}_{2}$ were separated by a $\mathrm{GC}$ column packed with porous silica beads (Unibeads IS, Alltech Associates) and quantified by a thermal conductivity detector (Gow Mac Corporation). The $\mathrm{CO}_{2}$ peak was collected in a cryogenic trap $\left(-196^{\circ} \mathrm{C}\right)$ fashioned from six loops of $1 / 8$ inch $(0.318 \mathrm{~cm})$ stainless steel tubing. The helium was pumped away, and the $\mathrm{CO}_{2}$ was transferred to a Pyrex breakseal ampoule for introduction to the isotope ratio mass spectrometer.

For $\delta^{13} \mathrm{C}-\mathrm{CH}_{4}$ analysis, $10-\mathrm{mL}$ whole sediment was transferred to a $60-\mathrm{mL}$ serum vial containing 5-mL $1 \mathrm{~N} \mathrm{NaOH}$ and sealed with a black butyl rubber stopper. The sample and base were thoroughly slurried and an aliquot of the headspace was transferred to a gas-tight syringe and injected into a combustion line. The sample was flushed with helium carrier gas through a cryogenic trap $\left(-196^{\circ} \mathrm{C}\right)$ to remove $\mathrm{CO}_{2}$ and $\mathrm{H}_{2} \mathrm{O}$ and into a combustion tube packed with $\mathrm{CuO}$ at $780^{\circ} \mathrm{C}$. The $\mathrm{CO}_{2}$ and $\mathrm{H}_{2} \mathrm{O}$ resulting from methane combustion were passed thru a multiloop trap maintained at $-120^{\circ} \mathrm{C}$ (to remove $\mathrm{H}_{2} \mathrm{O}$ ), and the $\mathrm{CO}_{2}$ was collected in a breakseal ampoule.

Carbon isotopic analyses were performed with a Delta $\mathrm{E}$ ratio mass spectrometer (Finnigan-Mat) equipped with a modified low-volume inlet system [Hayes et al., 1977]. The precision of the $\delta^{13} \mathrm{C}$ analysis was $\pm 0.1 \%$.

\section{RESULTS}

Changes in sulfate, methane, acetate, and $\mathrm{\Sigma CO}_{2}$ concentrations during the 114-day incubation period are summarized in Figure 2. The sulfate concentration decreased from $18.6 \mathrm{mM}$ at the outset to $0.19 \mathrm{mM}$ at 42 days (Figure 2a). After 50 days, sulfate leveled off at 10 to $20 \mu \mathrm{M}$, comparable to the threshold concentration below which sulfate reduction stops for pure cultures of Desulfobacter postgatei [Ingvorsen et al., 1984].

The methane concentration remained relatively constant $(\sim 0.2 \mathrm{mM})$ until sulfate was depleted to $<0.2 \mathrm{mM}$ (Figure 2a). Following sulfate depletion, the methane concentration increased, exceeding the saturation level (1.2 mM [Yamamota et al., 1976]) after 70 days. Since the immobilized magnum syringe piston restricted headspace formation, subsequent methane production resulted in a pressure buildup. The coupling that sealed the piston to the barrel was not capable of containing positive pressures and methane was inadvertently lost. The 

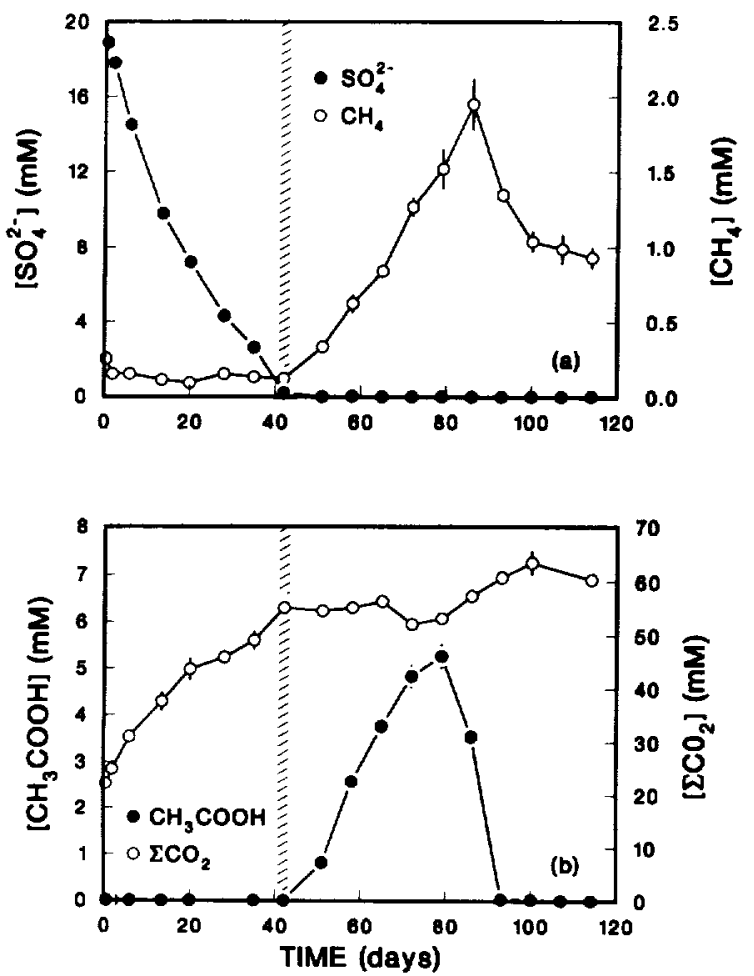

Fig. 2. Changes in pore water concentrations during the 114-day incubation period. (a) Sulfate and methane; (b) acetate and $\Sigma \mathrm{CO}_{2}$. With the exception of acetate, error bars represent the standard deviation of triplicate analyses. A standard deviation of $\pm 5 \%$ is assumed for acetate concentrations. The absence of an error bar indicates that the standard deviation is smaller than the symbol. The hatched line denotes the time that pore water sulfate concentrations were depleted to $<0.2 \mathrm{mM}$.

decrease in methane concentration after 85 days is due to gas loss from the magnum syringe rather than net methane consumption (see below).

The acetate concentration ranged from 1 to $9 \mu \mathrm{M}$ during the initial 42-day period when sediment contained appreciable sulfate (Figure $2 b$ ). Acetate concentrations $<10 \mu \mathrm{M}$ are typical for sulfatecontaining marine sediment [Ingvorsen et al., 1984]. Following sulfate depletion, acetate began to accumulate in the sediment, reaching a peak concentration of $5.3 \mathrm{mM}$ at $\sim 80$ days. The period of acetate accumulation was immediately followed by a period of dramatic depletion as concentrations fell to $5 \mu \mathrm{M}$ in just 14 days.

The $\mathrm{\Sigma CO}_{2}$ concentration increased rapidly during the period that sediment contained sulfate (Figure 2b). Sulfate and $\Sigma \mathrm{CO}_{2}$ concentrations during the initial 42-day period are highly correlated $\left(r^{2}=0.99\right)$, suggesting that sulfate served as the dominant terminal electron acceptor for organic matter remineralization. The slope of the $\Sigma \mathrm{CO}_{2}$ versus sulfate plot $\left(\Delta\left[\Sigma \mathrm{CO}_{2}\right] / \Delta\left[\mathrm{SO}_{4}^{2-}\right]\right)$ is $-1.7 \pm 0.1$, suggesting that sediment organic carbon remineralized in the magnum syringe experiment had an average oxidation state somewhat less than carbon in pure carbohydrate.

The rate of increase of $\Sigma \mathrm{CO}_{2}$ tapered off following sulfate depletion. This is primarily due to a delay in $\mathrm{\Sigma CO}_{2}$ production caused by pooling of carbon in the acetate reservoir. However, the gas loss that occurred when methane concentrations exceeded saturation may also have contributed to a reduced rate of dissolved $\Sigma \mathrm{CO}_{2}$ accumulation. Gas equilibrated with sediment pore waters $(\mathrm{pH} 7)$ having a $\mathrm{\Sigma CO}_{2}$ concentration of $50 \mathrm{mM}$ will have a $\mathrm{CO}_{2}$ partial pressure of $0.2 \mathrm{~atm}$ [Stumm and Morgan, 1981]. Therefore $\mathrm{\Sigma CO}_{2}$ concentrations in samples collected after methane concentrations exceeded saturation should be regarded as lower limits.

Sulfate reduction, methane oxidation, and methane production rates are presented in Figure 3. Sulfate reduction rates measured by the ${ }^{35} \mathrm{~S}$ tracer method are consistent with rates calculated from changes in sulfate concentration. Sulfate reduction rates fell off rapidly from the outset (Figure 3a), suggesting a rapid depletion of the most reactive fraction of the organic carbon pool [Westrich and Berner, 1984]. Since sulfate concentrations throughout most of the sulfate reduction period were well in excess of the half-saturation constant for sulfate reducing bacteria (0.2 $\mathrm{mM}$ [Ingvorsen et al., 1984]), it is unlikely that the initial decline in the sulfate reduction rate was due to sulfate limitation.

Methane oxidation rates remained near baseline level throughout the period that sediment contained sulfate (Figure $3 \mathrm{a}$ ). Note that methane concentrations during the initial 42 days ( $\sim 0.2 \mathrm{mM}$, Figure $2 \mathrm{a}$ ) were sufficient to support moderate rates of oxidation. Following sulfate depletion, methane oxidation rates began to increase, achieving maximum values between 80 and 100 days. The methane oxidation rate at all times represents a small fraction ( 1 to $8 \%$ ) of the total methane production rate (see below). Methane oxidation rates integrated over the 114-day experiment account for only $2.4 \%$ of the integrated methane production. Net methane oxidation was not observed during this experiment. 

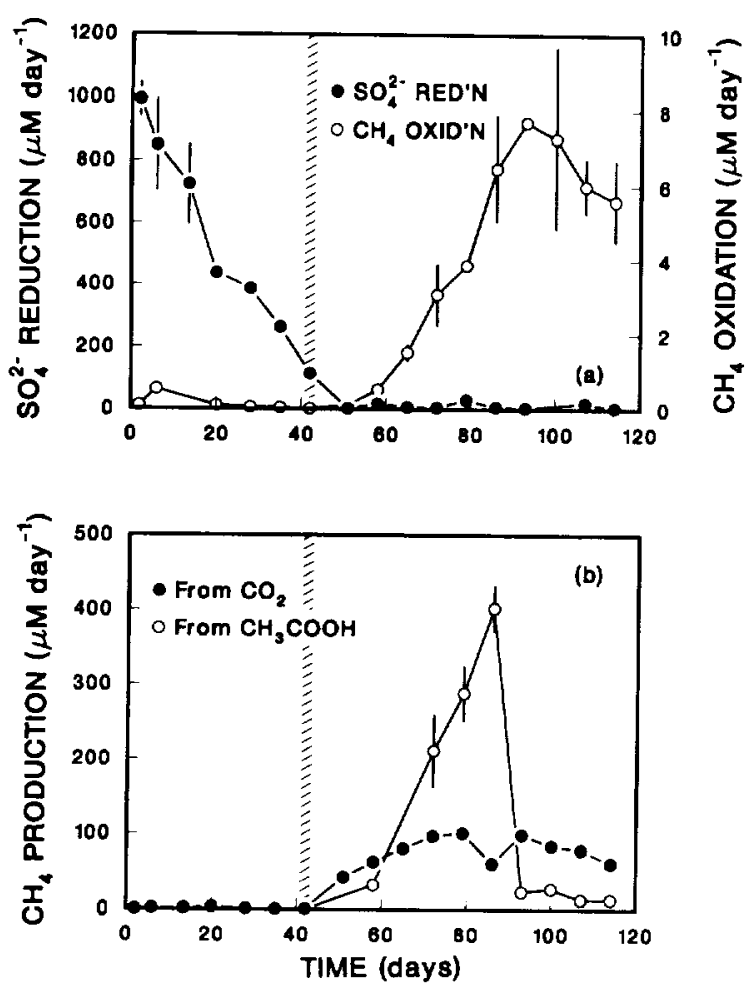

Fig. 3. Changes in rates of microbial processes during the 114-day incubation period. (a) Sulfate reduction and methane oxidation; (b) methane production from $\mathrm{CO}_{2}$ and acetate. Rates of methane production from acetate at 93 and 107 days are considered to be underestimated because 40 to $60 \%$ of the tracer turned-over during the incubation period. The error bars represent the standard deviation of rates measured in two to four (generally 3 ) replicate samples. The absence of an error bar indicates that the standard deviation is smaller than the symbol. The hatched line denotes the time that pore water sulfate concentrations were depleted to $<0.2 \mathrm{mM}$.

Methane production rates from $\mathrm{CO}_{2}$ and acetate were negligible during the period that sediment contained sulfate (Figure $3 \mathrm{~b}$ ). The absence of $\mathrm{CO}_{2}$ reduction and acetate fermentation in the presence of sulfate is consistent with the well-established principle that sulfate-reducing bacteria out-compete methanogens for $\mathrm{H}_{2}$ and acetate [Kristjansson et al., 1982; Schonheit et al., 1982]. Following sulfate depletion, methane production rates from $\mathrm{CO}_{2}$ and acetate began to increase, but the two methanogenic pathways followed very different patterns. Methane production from $\mathrm{CO}_{2}$ increased steadily, reached a maximum rate of $\sim 100 \mu \mathrm{M} \mathrm{d}^{-1}$, and gradually declined. In contrast, methane production from acetate began relatively slowly, increased sharply to $\sim 400 \mu \mathrm{M} \mathrm{d}^{-1}$, and then decreased dramatically to very low levels.

Relatively constant methane concentrations (Figure 2a) and very low rates of oxidation in sulfate-containing sediment (Figure $3 a$ ) suggest little methane production from "noncompetitive" substrates (i.e., compounds not metabolized by sulfatereducing bacteria). Therefore acetate fermentation and $\mathrm{CO}_{2}$ reduction are assumed to be the dominant pathways for methane production throughout the experiment. Total methane production rates (Figure 4a) are calculated as the sum of methane production from $\mathrm{CO}_{2}$ and methane production from acetate.
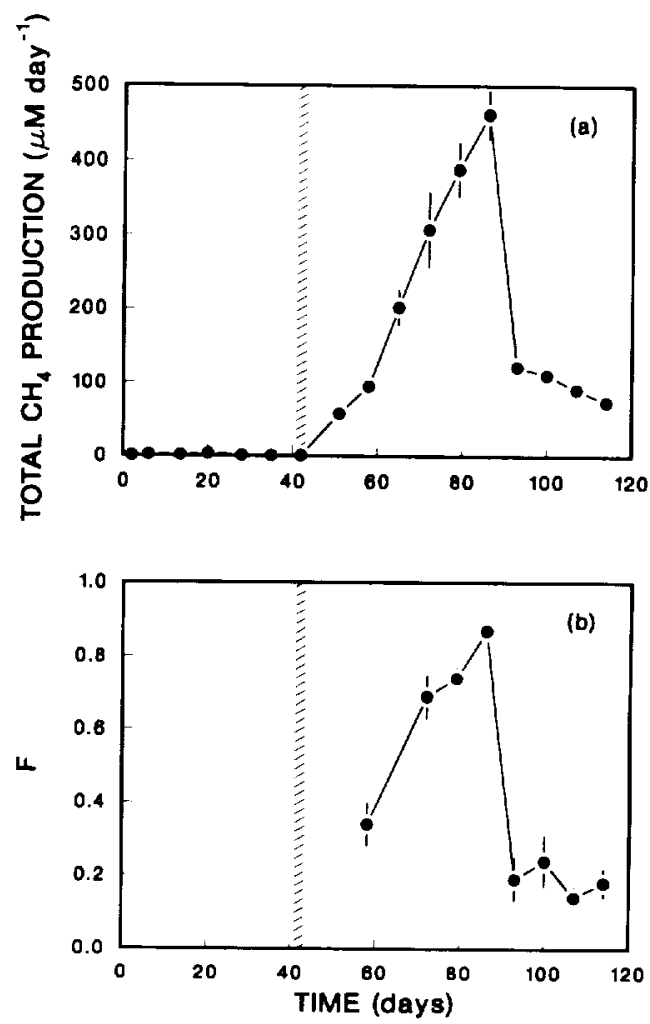

Fig. 4. Changes in total methane production rates and pathways during the 114-day incubation period. (a) Total methane production rates; (b) fraction of methane derived from acetate $(F)$. The error bars were calculated by error propagation. The absence of an error bar indicates that the standard deviation is smaller than the symbol. The hatched line denotes the time that pore water sulfate concentrations were depleted to $<0.2 \mathrm{mM}$. 
The fraction of methane derived from acetate (F) varied considerably over the course of the experiment (Figure $4 \mathrm{~b}$ ). Following the sulfate-methane transition, $\mathrm{CO}_{2}$ reduction accounted for the bulk of the methane production. As acetate accumulated in the pore waters (Figure 2b), the methanogenic pathway shifted and acetate became the major methane precursor. Acetate fermentation dominated methane production until the acetate reservoir was fully depleted. At this point, $\mathrm{CO}_{2}$ reduction resumed its role as the dominant methanogenic pathway. Over the course of the experiment, acetate fermentation accounted for nearly $60 \%$ of the total methane production.

The $\Sigma \mathrm{CO}_{2}$ and methane reservoir experienced large changes in isotopic composition over the course of the 114-day experiment (Figure 5). During the period that sediment contained sulfate, $\delta^{13} \mathrm{C}-\Sigma \mathrm{CO}_{2}$ values decreased only slightly (Figure 5a), despite a large increase in $\Sigma \mathrm{CO}_{2}$ concentration (Figure $2 \mathrm{~b}$ ).
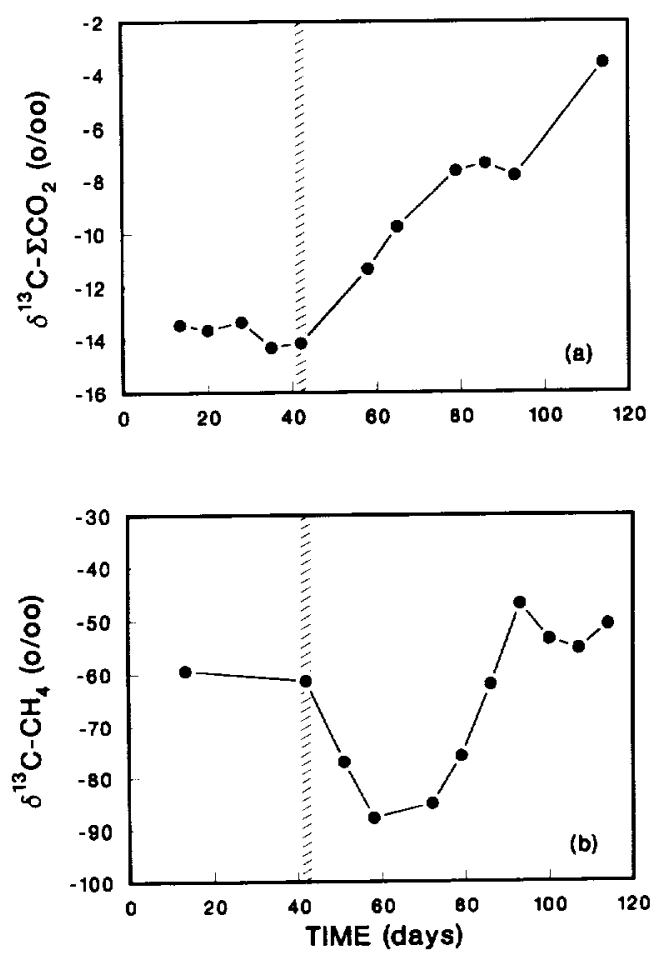

Fig. 5. Changes in $\delta^{13} \mathrm{C}$ values during the 114-day incubation period. (a) $\delta^{13} \mathrm{C}-\Sigma \mathrm{CO}_{2}$; (b) $\delta^{13} \mathrm{C}_{-}-\mathrm{CH}_{4}$. Samples were not analyzed for $\delta^{13} \mathrm{C}$ during the first 6 days of the experiment. The hatched line denotes the time that pore water sulfate concentrations were depleted to $<0.2 \mathrm{mM}$.
This suggests that the $\mathrm{CO}_{2}$ produced by organic matter remineralization had a $\delta^{13} \mathrm{C}$ similar to the initial value of the $\Sigma \mathrm{CO}_{2}$ pool. Following sulfate depletion, the $\Sigma \mathrm{CO}_{2}$ reservoir became progressively enriched in ${ }^{13} \mathrm{C}$.

The $\delta^{13} \mathrm{C}-\mathrm{CH}_{4}$ values remained nearly constant ( -59 to $-61 \%$ ) prior to the onset of methanogenesis (Figure $5 b$ ). The low methane concentrations during this initial period reflect methane that was present in the 0 to $3 \mathrm{~cm}$ interval at the time the sediment was collected. The initial ${ }^{13} \mathrm{C}_{-} \mathrm{CH}_{4}$ values are similar to those for methane in gas bubbles collected from Cape Lookout Bight sediment in July ( -59 to $-62 \%$ )

[Martens et al., 1986; Burke et al., 1987]. Following sulfate depletion, the methane reservoir underwent substantial variations in $\delta^{13} \mathrm{C}$. The $\delta^{13} \mathrm{C}_{-}-\mathrm{CH}_{4}$ initially dropped from -61 to $-88 \%$, gradually increased to $-47 \%$, and decreased slightly toward the end of the experiment.

\section{DISCUSSION}

The isotopic composition of methane in the magnum syringe varied by more than $40 \%$ over the course of the experiment (Figure 5b). In the following section, we evaluate the relative importance of changes in methanogenic pathway, precursor isotopic composition, and kinetic isotope effects in controlling the observed variations in $\delta^{13} \mathrm{C}_{-} \mathrm{CH}_{4}$. Since integrated rates of methane production are $\sim 40$ times greater than methane oxidation, it is unlikely that methane oxidation played an important role in controlling the isotopic composition of methane.

The discussion is divided into four sections. The first section examines the relationship between $\delta^{13} \mathrm{C}_{-}-\mathrm{CH}_{4}$ and the methane production pathway. The second section provides constraints on variations in the isotopic composition of the major methane precursors $\left(\mathrm{CO}_{2}\right.$ and acetate). The third section describes the microbial interactions that may have played a role in regulating both methane production pathways and substrate isotopic composition. The final section compares the results of the microcosm experiment with in situ seasonal variations in isotopic composition of methane emitted from Cape Lookout Bight sediments.

\section{$\mathrm{\delta}^{3} \mathrm{C}-\mathrm{CH}_{4}$ Versus Methane Production Pathway}

Measured $\delta^{13} \mathrm{C}_{-} \mathrm{CH}_{4}$ values (Figure $5 \mathrm{~b}$ ) reflect the isotopic composition of methane accumulated in 
the magnum syringe. Before we can examine the relationship between $\delta^{13} \mathrm{C}^{-} \mathrm{CH}_{4}$ and methane production pathway, the $\delta^{13} \mathrm{C}$ of the methane produced during a discrete time interval must be determined by an isotope mass balance calculation. Since the positive pressures that developed in the magnum syringe when methane concentrations exceeded saturation resulted in gas loss, methane concentrations must be corrected before mass balance constraints can be applied.

Methane concentrations corrected for gas loss. Methane concentrations calculated by integrating production rate data are unaffected by gas loss from the magnum syringe and therefore reflect the total quantity of methane produced during the experimental period. The methane concentration at time $t_{2}$ is equal to the concentration at time $t_{1}$ plus the time integral of the total methane production rate (MPR) (Figure 4a):

$$
\left[\mathrm{CH}_{4}\right]_{2}=\left[\mathrm{CH}_{4}\right]_{1}+\int_{1}^{2} \mathrm{MPR} d t \text {. }
$$

Calculated (equation (1)) and measured concentrations began to diverge as the methane concentration approached saturation (Figure 6). By the end of the experiment (114 days), the measured methane concentration represents less than $10 \%$ of the calculated value.

Isotopic composition of methane produced. The isotopic composition of methane produced in the magnum syringe $\left(\delta^{13} \mathrm{C}-\mathrm{MP}\right)$ during any discrete time interval (e.g., $t_{1}$ to $t_{2}$ ) can he calculated by an isotope mass balance equation:

$$
\begin{aligned}
& \delta^{13} \mathrm{C}-\mathrm{MP}= \\
& \frac{\left(\delta^{13} \mathrm{C}-\mathrm{CH}_{4}\right)_{2}\left[\mathrm{CH}_{4}\right]_{2}-\left(\delta^{13} \mathrm{C}-\mathrm{CH}_{4}\right)_{1}\left[\mathrm{CH}_{4}\right]_{1}}{\left[\mathrm{CH}_{4}\right]_{\text {PROD }}}
\end{aligned}
$$

where $\left[\mathrm{CH}_{4}\right]_{\text {PROD }}$ is the concentration of methane produced during the time interval $t_{1}$ to $t_{2}$.

Two factors must be considered before applying (2) to the magnum syringe experiment. First, the gas phase that appeared when methane concentrations exceeded saturation could lead to isotopic fractionation if there was an isotope effect associated with transfer of dissolved methane to the gas phase. Bernard et al. [1976] have shown that there is little isotopic fractionation between $\mathrm{CH}_{4}(\mathrm{ag})$ and $\mathrm{CH}_{4}(\mathrm{~g})$

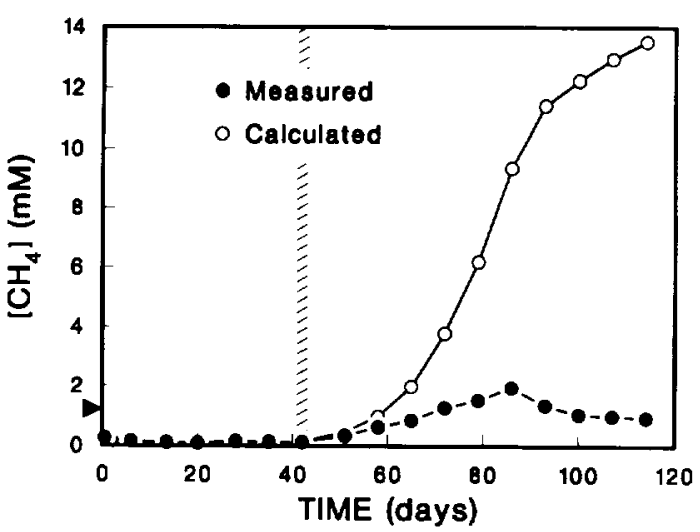

Fig. 6. Changes in measured and calculated methane concentrations during the 114-day incubation period. The method used to calculate methane concentrations is described in the text. The arrow on the concentration axis marks the dissolved methane concentration equivalent to a partial pressure of $1 \mathrm{~atm}$. The hatched line denotes the time that pore water sulfate concentrations were depleted to $<0.2 \mathrm{mM}$.

$(0.3 \%)$, so formation of a gas phase would not have an appreciable effect on the isotopic composition of the dissolved methane pool.

Application of (2) is further complicated by the large fraction of the methane production that was lost from the magnum syringe when positive pressures developed (Figure 6). Since effusive transport discriminates between ${ }^{12} \mathrm{C}$ - and ${ }^{13} \mathrm{C}$-methane according to Graham's law [Mason and Kronstadt, 1967], gas loss via this mechanism would cause methane remaining in the magnum syringe to become enriched in ${ }^{13} \mathrm{C}$. In order for effusive transport to occur, methane must pass through an orifice without colliding with other gas molecules. This requires that the diameter of the leak in the O-ring seal be less that the mean free path of the methane molecule $(46 \mathrm{~nm})$. The effusive flux through a hole this size can be calculated [Mason and Evans, 1969] by assuming the leak to have cylindrical geometry with length equal to the $O$-ring cross section $(3 \mathrm{~mm}$ ). The effusive flux $\left(\sim 10^{-8} \mathrm{mmol} \mathrm{d}^{-1}\right)$ is 7 orders-of-magnitude less than the actual leak rate $\left(0.1\right.$ to $\left.0.4 \mathrm{mmol} \mathrm{d}^{-1}\right)$ estimated from the difference between calculated and measured methane concentrations (Figure 6). This implies that pressure-driven gas transport from the magnum syringe must have occurred by other mechanisms. Since there is no mass discrimination during turbulent or viscous flow [Halsted and Nier, 1950], gas loss through faults in the O-ring coupling is unlikely to alter the $\delta^{13} \mathrm{C}$ value of the methane. 
Methane loss did reduce the size of the reservoir, however, so that the isotopic composition of any methane produced had a proportionately greater effect on the cumulative $\delta^{13} \mathrm{C}$. The effect of gas loss on the isotopic composition of the methane reservoir was corrected in the following way. Cubic spline functions [Ahlberg et al., 1967] were fit to the measured and calculated methane concentration (Figure 6) and $\delta^{13} \mathrm{C}_{-} \mathrm{CH}_{4}$ data (Figure 5 b) to allow interpolation at any $t_{1}$ and $t_{2}$. Loss of methane from the magnum syringe was compensated by calculating the methane concentration at $t_{2}$ as

$\left[\mathrm{CH}_{4}\right]_{2}=\left[\mathrm{CH}_{4}\right]_{1}+\left[\mathrm{CH}_{4}\right]_{\mathrm{PROD}}$,

where $\left[\mathrm{CH}_{4}\right]_{\mathrm{PROD}}=\left[\mathrm{CH}_{4}\right]_{2}^{*}-\left[\mathrm{CH}_{4}\right]_{1}^{*}$.

The asterisks indicate calculated (as opposed to measured) methane concentrations. Thus $\left[\mathrm{CH}_{4}\right]_{2}$ in (3) represents the methane concentration that would be present at $t_{2}$ if there was no gas loss during the time interval $t_{1}$ to $t_{2}$. Any gas loss is treated as though it occurred during an infinitesimal time interval just after $t_{2}$.

The $\delta^{13} \mathrm{C}$ of methane produced during the time interval $t_{1}$ to $t_{2}$ was corrected for the effect of gas loss by combining (2), (3), and (4). The time step $\left(t_{2}-t_{1}\right)$ was made sufficiently small ( 0.1 day) that the calculated $\delta^{13} \mathrm{C}$-MP closely approximates the $\delta^{13} \mathrm{C}$ of methane produced during any instant. The $\delta^{13} \mathrm{C}$ value of methane produced during a finite time interval (e.g., between consecutive magnum syringe samples) was then calculated by integrating instantaneous $\left[\mathrm{CH}_{4}\right]_{\mathrm{RROD}}$ and $\delta^{13} \mathrm{C}$-MP values:

$\delta^{13} \mathrm{C}-\mathrm{MP}=\frac{\int_{A}^{\mathrm{B}}\left(\left[\mathrm{CH}_{4}\right]_{\mathrm{PROD}} \delta^{13} \mathrm{C}-\mathrm{MP}\right) d t}{\int_{A}^{\mathrm{B}}\left[\mathrm{CH}_{4}\right]_{\text {PROD }} \mathrm{dt}}$,

where $A$ and $B$ represent the beginning and end of the time interval of interest.

The $\delta^{13} \mathrm{C}$ of methane produced by the sediment microcosm (calculated by equation (5)) varied between -94 and $-42 \%$ (Figure 7 ). The range $(52 \%)$ is greater than that of the measured values because the cumulative reservoir represents an integrated isotopic composition. The isotopic composition of the cumulative reservoir tracks $\delta^{13} \mathrm{C}$-MP fairly closely (cf. Figures $5 \mathrm{~b}$ and 7 ) hecause methane continuously escaped from the magnum syringe once the methane concentration exceeded saturation.

There is no simple relationship between the $\delta^{13} \mathrm{C}$ of the methane produced in the magnum syringe and the methane production pathway. For example, $\mathrm{CO}_{2}$ reduction dominated methane production (accounting for $\sim 70 \%$ of total production) both at the outset of the methanogenic period and toward the end of the experiment (Figure 4b). However, methane produced during the initial period (-80 to $-94 \%$, Figure 7 ) was highly depleted in ${ }^{13} \mathrm{C}$ relative to the methane produced during the later period $(-46$ to $-60 \%$ ). A simple relationship between $\delta^{13} \mathrm{C}-\mathrm{CH}_{4}$ and methane production pathway is expected only if the methane produced by each mechanism has a distinct isotopic composition. The absence of such a relationship indicates variability in the $\delta^{13} \mathrm{C}$ value of methane produced by a particular pathway. Such variability can be driven by changes in the isotopic composition of the methane precursors $\left(\mathrm{CO}_{2}\right.$ and acetate) and/or changes in the magnitude of the kinetic isotopic effect associated with each methane production mechanism.

Overall isotope mass balance. Conservation of mass requires that the end products of organic matter degradation $\left(\mathrm{CO}_{2}\right.$ and methane) have the same cumulative isotopic composition as the remineralized organic carbon. The isotopic composition of the

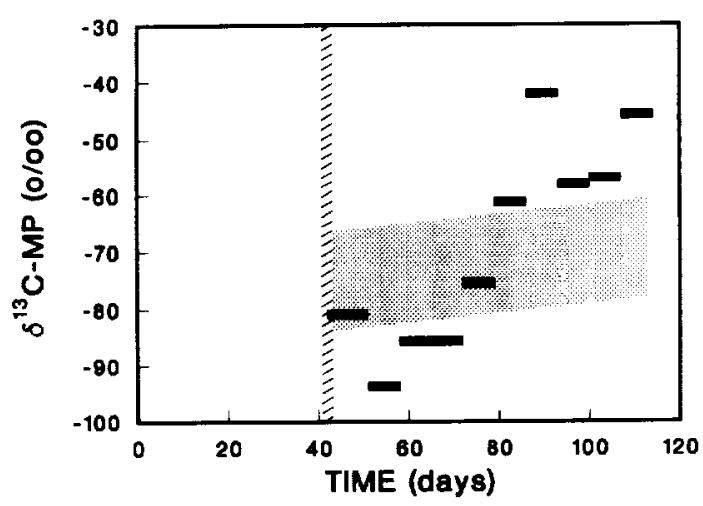

Fig. 7. Changes in isotopic composition of methane produced $\left(\delta^{13} \mathrm{C}-\mathrm{MP}\right)$ during the 114-day incubation period. The solid horizontal bars represent the $\delta^{13} \mathrm{C}$ of methane produced between consecutive sampling intervals. The shaded region represents the $\delta^{13} \mathrm{C}$ of methane produced by $\mathrm{CO}_{2}$ reduction. Details of the calculations are given in the text. The hatched line denotes the time that pore water sulfate concentrations were depleted to $<0.2 \mathrm{mM}$. 
labile organic carbon should not be directly affected by the nature of the terminal electron acceptor. Therefore the $\delta^{13} \mathrm{C}$ of organic carbon remineralized during the period of sulfate reduction $\left(\delta^{13} \mathrm{C}-\mathrm{C}_{\mathrm{ORG}}[\mathrm{SR}]\right)$ should be similar to the $\delta^{13} \mathrm{C}$ of organic carbon remineralized during the period of methane production $\left(\delta^{13} \mathrm{C}-\mathrm{C}_{\mathrm{ORG}}[\mathrm{MP}]\right)$.

Since $\mathrm{CO}_{2}$ is the sole end product of organic matter decomposition in sulfate-containing sediments (Figure 2), the $\delta^{13} \mathrm{C}$ of organic carbon remineralized during the period of sulfate reduction is simply calculated as the $\delta^{13} \mathrm{C}$ value of the $\Sigma \mathrm{CO}_{2}$ produced:

$$
\begin{gathered}
\delta^{13} \mathrm{C}-\mathrm{C}_{\mathrm{ORG}}[\mathrm{SR}]=\frac{\left(\delta^{13} \mathrm{C}-\Sigma \mathrm{CO}_{2}\right)_{\mathrm{FN}}\left[\Sigma \mathrm{CO}_{2}\right]_{\mathrm{FIN}}}{\left[\Sigma \mathrm{CO}_{2}\right]_{\mathrm{FIN}}-\left[\Sigma \mathrm{CO}_{2}\right]_{\mathrm{INI}}} \\
-\frac{\left(\delta^{13} \mathrm{C}-\Sigma \mathrm{CO}_{2}\right)_{\mathrm{INI}}\left[\Sigma \mathrm{CO}_{2}\right]_{\mathrm{INI}}}{\left[\Sigma \mathrm{CO}_{2}\right]_{\mathrm{FIN}}-\left[\Sigma \mathrm{CO}_{2}\right]_{\mathrm{INI}}}
\end{gathered}
$$

where INI and FIN denote $\left[\Sigma \mathrm{CO}_{2}\right]$ or $\delta^{13} \mathrm{C}-\Sigma \mathrm{CO}_{2}$ at the start of the experiment and at the time that sulfate became depleted (day 42), respectively. Between 14 and 42 days, the $\Sigma \mathrm{CO}_{2}$ concentration increased from 37.6 to $55.2 \mathrm{mM}$ (Figure $2 \mathrm{~b}$ ), while the $\delta^{13} \mathrm{C}-\mathrm{\Sigma CO}_{2}$ decreased from -13.4 to $-14.1 \%$ (Figure 5a). The $\delta^{13} \mathrm{C}$ value of organic carbon remineralized during the period of sulfate reduction $\left(\delta^{13} \mathrm{C}-\mathrm{C}_{\mathrm{ORG}}[\mathrm{SR}]\right)$ is $-15.6 \%$ (equation (6)). This value differs from the $\delta^{13} \mathrm{C}$ of the bulk organic carbon in Cape Lookout Bight sediments ( -18 to $-20 \%$ [Blair et al., 1987; Martens et al., 1992; Blair and Carter, 1992], suggesting preferential remineralization of an organic matter component that is enriched in ${ }^{13} \mathrm{C}$ relative to the bulk phase. This result seems to contradict previous studies showing no downcore variations in $\delta^{13} \mathrm{C}$ of particulate organic carbon in sediments from Cape Lookout Bight [Blair et al., 1987; Martens et al., 1992; Blair and Carter, 1992]. However, the quantity of organic carbon converted to $\mathrm{CO}_{2}$ and methane during the 114-day experiment $(40.4 \mathrm{mM})$ represents a small fraction $(-2 \%)$ of the particulate organic carbon pool. Therefore it is not surprising that preferential remineralization of a ${ }^{13} \mathrm{C}$-rich labile fraction is not detected in $\delta^{13} \mathrm{C}$ profiles of total organic carbon.

Since $\mathrm{CO}_{2}$ and methane are both end products of organic matter decomposition in sulfate-depleted sediments, the isotopic composition of organic carbon remineralized during the period of methane production is calculated as the weighted average $\delta^{13} \mathrm{C}$ of the $\Sigma \mathrm{CO}_{2}$ and methane produced:

$$
\begin{aligned}
& \delta^{13} \mathrm{C}-\mathrm{C}_{\mathrm{ORG}}[\mathrm{MP}]= \\
& \frac{\left(\delta^{13} \mathrm{C}-\Sigma \mathrm{CO}_{2}\right)_{\mathrm{FIN}}\left[\Sigma \mathrm{CO}_{2}\right]_{\mathrm{FIN}}}{\left[\Sigma \mathrm{CO}_{2}\right]_{\mathrm{FIN}}-\left[\Sigma \mathrm{CO}_{2}\right]_{\mathrm{INI}}+\left[\mathrm{CH}_{4}\right]_{\mathrm{FIN}}-\left[\mathrm{CH}_{4}\right]_{\mathrm{INI}}}- \\
& \frac{\left(\delta^{13} \mathrm{C}-\Sigma \mathrm{CO}_{2}\right)_{\mathrm{INI}}\left[\Sigma \mathrm{CO}_{2}\right]_{\mathrm{INI}}}{\left[\Sigma \mathrm{CO}_{2}\right]_{\mathrm{FIN}}-\left[\Sigma \mathrm{CO}_{2}\right]_{\mathrm{INI}}+\left[\mathrm{CH}_{4}\right]_{\mathrm{FIN}}-\left[\mathrm{CH}_{4}\right]_{\mathrm{INI}}}+ \\
& \frac{\left(\delta^{13} \mathrm{C}-\mathrm{CH}_{4}\right)_{\mathrm{FIN}}\left[\mathrm{CH}_{4}\right]_{\mathrm{FIN}}}{\left[\Sigma \mathrm{CO}_{2}\right]_{\mathrm{FIN}}-\left[\Sigma \mathrm{CO}_{2}\right]_{\mathrm{INI}}+\left[\mathrm{CH}_{4}\right]_{\mathrm{FIN}}-\left[\mathrm{CH}_{4}\right]_{\mathrm{INI}}} . \\
& \frac{\left(\delta^{13} \mathrm{C}-\mathrm{CH}_{4}\right)_{\mathrm{INI}}\left[\mathrm{CH}_{4}\right]_{\mathrm{INI}}}{\left[\Sigma \mathrm{CO}_{2}\right]_{\mathrm{FIN}}-\left[\Sigma \mathrm{CO}_{2}\right]_{\mathrm{INI}}+\left[\mathrm{CH}_{4}\right]_{\mathrm{FIN}}-\left[\mathrm{CH}_{4}\right]_{\mathrm{INI}}}
\end{aligned}
$$

where INI and FIN denote the concentration or $\delta^{13} \mathrm{C}$ value at the start of the methane production period (day 42) and at the end of the experiment (day 114), respectively. The $\Sigma \mathrm{CO}_{2}$ and methane concentrations at day 42 were 55.2 and $0.12 \mathrm{mM}$, respectively (Figure 2). The final methane concentration (13.5 mM, Figure 6) was calculated by correcting for gas loss using (1). The final $\Sigma \mathrm{CO}_{2}$ concentration (64.6 $\mathrm{mM}$ ) was also corrected for gas loss using an equation analogous to (1). The $\Sigma \mathrm{CO}_{2}$ production rate was set equal to 0.7 times the total methane production rate (MPR). This stoichiometry is based on the oxidation state of labile organic carbon inferred from the $\Delta \Sigma \mathrm{CO}_{2} / \Delta \mathrm{SO}_{4}{ }^{2-}$ ratio $(-1.7)$. The $\delta^{13} \mathrm{C}-\mathrm{CH}_{4}$ and $\delta^{13} \mathrm{C}-\Sigma \mathrm{CO}_{2}$ values at day 42 were $-61.4 \%$ and $-14.1 \%$, respectively (Figure 5 ). The final $\delta^{13} \mathrm{C}$ $\mathrm{CH}_{4}$ value $(-66.6 \%$ was corrected for gas loss by integrating $\delta^{13} \mathrm{C}$-MP (equation (5)) over the entire 114-day interval. Note that this value represents the cumulative $\delta^{13} \mathrm{C}_{-} \mathrm{CH}_{4}$ and differs substantially from the measured value at day $114(-50.8 \%)$. The final $\delta^{13} \mathrm{C}-\mathrm{CCO}_{2}$ value $(-3.9 \%$ was also corrected for gas loss using an equation analogous to (5). However, for the $\Sigma \mathrm{CO}_{2}$ pool, isotopic fractionation between $\Sigma \mathrm{CO}_{2}(\mathrm{aq})$ and $\mathrm{CO}_{2}(\mathrm{~g})$ [Deuser and Degens, 1967; Wendt, 1968] was taken into account. The $\delta^{13} \mathrm{C}$ value of organic carbon remineralized during the period of methane production $\left(\delta^{13} \mathrm{C}-\mathrm{C}_{\mathrm{ORG}}[\mathrm{MP}]\right)$ is $-16.0 \%$ (equation (7)).

The isotope mass balance provides a check on the accuracy of the $\delta^{13} \mathrm{C}$-MP calculation. The $\delta^{13} \mathrm{C}$ value of organic carbon remineralized during the period of sulfate reduction $\left(\delta^{13} \mathrm{C}-\mathrm{C}_{\mathrm{ORG}}[\mathrm{SR}]\right)$ is based entirely on measured concentration and $\delta^{13} \mathrm{C}$ values. In 
contrast, the $\delta^{13} \mathrm{C}$ value of organic carbon remineralized during the period of methane production $\left(\delta^{13} \mathrm{C}-\mathrm{C}_{\mathrm{ORG}}[\mathrm{MP}]\right)$ is based on concentration and $\delta^{13} \mathrm{C}$ values corrected for gas loss according to (2)-(5). Agreement between $\delta^{13} \mathrm{C}-\mathrm{C}_{\mathrm{ORG}}[\mathrm{SR}](-15.6 \%)$ and $\delta^{13} \mathrm{C}-\mathrm{C}_{\text {ORG }}[\mathrm{MP}](-16.0 \%)$ indicates that calculated $\delta^{13} \mathrm{C}-\mathrm{MP}$ values are consistent with the constraint that the microcosm maintain an overall isotope mass balance.

\section{$\delta^{13} \mathrm{C}-\mathrm{CH}_{4}$ From $\mathrm{CO}_{2}$ and Acetate}

The relationship between $\delta^{13} \mathrm{C}-\mathrm{CH}_{4}$ and the methanogenic pathway can be complicated by concurrent changes in the isotopic composition of the methanogenic substrates $\left(\mathrm{CO}_{2}\right.$ and acetate) and/or variability in the magnitude of the kinetic isotope effect for the methane production pathways $\left(\mathrm{CO}_{2}\right.$ reduction and acetate fermentation). In this section, we examine how these factors may have played a role in controlling the stable carbon isotopic composition of methane produced by the sediment microcosm.

Methane from $\mathrm{CO}_{2}$ reduction. There is a large kinetic isotope effect associated with bacterial $\mathrm{CO}_{2}$ reduction to methane. The magnitude of this effect is expressed as an isotope fractionation factor $\left(\alpha_{\mathrm{CR}}\right)$, defined as the ratio of methane production rates from ${ }^{12} \mathrm{C}$ - and ${ }^{13} \mathrm{C}-\mathrm{CO}_{2}$ normalized to the isotopic abundance in the reactant molecule [Rees, 1973]:

$\alpha_{\mathrm{CR}}={ }^{{ }^{12} \mathrm{C}-\mathrm{MPC} /\left[{ }^{12} \mathrm{CO}_{2}\right]}$,

where MPC denotes the rate of methane production via $\mathrm{CO}_{2}$ reduction.

If we let $\mathrm{R}_{\mathrm{MPC}}={ }^{13} \mathrm{C}-\mathrm{MPC} /{ }^{12} \mathrm{C}-\mathrm{MPC}$ and

$\mathrm{R}_{\left[\mathrm{CO}_{2}\right]}=\left[{ }^{13} \mathrm{CO}_{2}\right] /\left[{ }^{12} \mathrm{CO}_{2}\right]$, (8) can be written as

$\mathrm{R}_{\mathrm{MPC}}=\frac{\mathrm{R}_{\left[\mathrm{CO}_{2}\right]}}{\alpha_{\mathrm{CR}}}$.

It follows from the definition of $\delta^{13} \mathrm{C}$ [Craig, 1957] that

$\delta^{13} \mathrm{C}-\mathrm{MPC}=\frac{\delta^{13} \mathrm{C}-\mathrm{CO}_{2}+10^{3}}{\alpha_{\mathrm{CR}}}-10^{3}$,

where $\delta^{13} \mathrm{C}$-MPC represents the isotopic composition of methane produced from $\mathrm{CO}_{2}$ reduction. This treatment assumes that $\mathrm{CO}_{2}$ (as opposed to $\mathrm{HCO}_{3}{ }^{-}$or
$\left.\mathrm{CO}_{3}{ }^{2-}\right)$ is the form of inorganic carbon utilized by methanogenic bacteria [Fuchs et al., 1979].

The isotopic composition of methane produced from $\mathrm{CO}_{2}$ at any time during the magnum syringe experiment can be determined from the $\delta^{13} \mathrm{C}$ of the $\mathrm{CO}_{2}$ pool and the isotope fraction factor (equation 10). While $\delta^{13} \mathrm{C}-\mathrm{CO}_{2}$ values are easily calculated from $\delta^{13} \mathrm{C}-\Sigma \mathrm{CO}_{2}$ data [Deuser and Degens, 1967], there is considerable uncertainty regarding the isotope fractionation factor for methane production from $\mathrm{CO}_{2}$. Laboratory cultures of methanogenic bacteria grown autotrophically on $\mathrm{H}_{2}-\mathrm{CO}_{2}$ yield fractionation factors that range from 1.025 to 1.061 (mean: 1.041, $\mathrm{n}=7$ ) [Oremland, 1988]. It is not clear whether this high degree of variability is due to differences in experimental conditions or differences between methanogenic species. For example, a single species (Methanobacterium thermoautotrophicum) grown in a sealed batch culture [Games and Hayes, 1976] and a flow-thru fermentation system [Fuchs et al., 1979] yielded isotope fractionation factors that differed by $10 \%$. Likewise, different species (Methanobacterium barkeri and Methanosarcina bryantii) grown under identical conditions had isotope fractionation factors that differed by $28 \%$ [Games and Hayes, 1976].

Aside from interspecies and intraspecies variability, there are reasons why in vitro fractionation factors may not apply to natural methanogen populations. First, the magnitude of the fractionation factor may be a function of the methane production rate. Laboratory cultures fed an $80 / 20(\mathrm{v} / \mathrm{v})$ mixture of $\mathrm{H}_{2}-\mathrm{CO}_{2}$ generally have higher production rates than methanogenic bacteria in natural ecosystems. Second, most laboratory measurements of isotope fractionation by methanogenic bacteria were conducted at elevated temperatures $\left(37^{\circ}\right.$ to $\left.65^{\circ} \mathrm{C}\right)$. Thermodynamics predicts that carbon isotope fractionation between $\mathrm{CO}_{2}$ and methane decreases with increasing temperature [Bottinga, 1969], although it is not clear whether the kinetic isotope effect for bacterial methane production follows the same relationship. Third, the isotope fractionation factor may be species-specific and the bacteria used in the culture studies are unlikely to be representative of natural methanogen populations.

One approach to deriving fractionation factors applicable to methanogenic populations in aquatic sediments is based on in situ isotopic differences between methane and $\mathrm{CO}_{2}$. In sediment where $\mathrm{CO}_{2}$ reduction is the exclusive methane source, the 
isotope fractionation factor can be estimated from paired $\delta^{13} \mathrm{C}-\mathrm{CO}_{2}$ and $\delta^{13} \mathrm{C}-\mathrm{CH}_{4}$ data (equation (10)). Evidence based on the deuterium content of methane and its formation water suggests that $\mathrm{CO}_{2}$ reduction is the dominant methanogenic pathway in many marine sediments [Whiticar et al., 1986]. An extensive compilation of paired $\delta^{13} \mathrm{C}-\mathrm{CH}_{4}$ and $\delta^{13} \mathrm{C}-\mathrm{CO}_{2}$ data from a wide variety of marine sediment environments predicts a fractionation factor for $\mathrm{CO}_{2}$ reduction of $1.070 \pm 0.020$ [Whiticar et al., 1986].

A more rigorous approach to estimating fractionation factors for $\mathrm{CO}_{2}$ reduction in aquatic sediments takes into account the contribution of different methane production pathways, the intramolecular isotopic composition of acetate, and the kinetic isotope effect for acetate fermentation. This approach was used to estimate fractionation factors for $\mathrm{CO}_{2}$ reduction in Cape Lookout Bight sediments [Blair et al., 1992]. Isotope fractionation factors for summer $(1.056 \pm 0.004)$ and winter $(1.062 \pm 0.002)$ conditions fall within the range of values calculated from the paired $\delta^{13} \mathrm{C}-\mathrm{CH}_{4}$ and $\delta^{13} \mathrm{C}-\mathrm{CO}_{2}$ data.

The isotope fractionation factors for Cape Lookout Bight sediment [Blair et al., 1992] were used to calculate $\delta^{13} \mathrm{C}-\mathrm{MPC}$ values (equation (10)) for methane produced by the sediment microcosm. An average $\alpha_{C R}$ value (1.06) was used because seasonal variations are relatively small. A rather large range $( \pm 0.01)$ was adopted to allow for uncertainty in the value of the isotope fractionation factor.

The stable carbon isotopic composition of methane derived from $\mathrm{CO}_{2}$ is denoted by the stippled region in Figure 7; the upper and lower limits correspond to $\alpha_{\mathrm{CR}}=1.05$ and $\alpha_{\mathrm{CR}}=1.07$, respectively. The trend toward more positive $\delta^{13} \mathrm{C}$-MPC values with time is due to the shift in $\delta^{13} \mathrm{C}-\Sigma \mathrm{CO}_{2}$ during the period of methane production (Figure 5a). The progressive enrichment of ${ }^{13} \mathrm{C}$ in the $\Sigma \mathrm{CO}_{2}$ pool is due, at least in part, to the kinetic isotope effect associated with $\mathrm{CO}_{2}$ reduction: ${ }^{12} \mathrm{CO}_{2}$ is converted to methane at a faster rate than ${ }^{13} \mathrm{CO}_{2}$, leaving the residual $\mathrm{\Sigma CO}_{2}$ pool isotopically heavier.

The methane produced between 50 and 75 days is depleted in ${ }^{13} \mathrm{C}$ compared to the methane produced by $\mathrm{CO}_{2}$ reduction. The methane produced after 85 days is enriched in ${ }^{13} \mathrm{C}$ relative to the methane derived from $\mathrm{CO}_{2}$. Although we cannot rule out the possibility that the isotope fractionation factor for $\mathrm{CO}_{2}$ reduction varied over the course of the experiment, $\alpha_{C R}$ values substantially less than 1.05 or greater than 1.07 are unlikely. Production of methane with $\delta^{13} \mathrm{C}$ values well outside the range expected for $\mathrm{CO}_{2}$ reduction are in all likelihood related to methane production from acetate.

Methane from acetate fermentation. The $\delta^{13} \mathrm{C}$ of methane produced from acetate $\left(\delta^{13} \mathrm{C}-\mathrm{MPA}\right)$ cannot be calculated directly (using an equation analogous to equation (10)) because the $\delta^{13} \mathrm{C}$ of acetate in the magnum syringe sediment is unknown. However, $\delta^{13} \mathrm{C}-\mathrm{MPA}$ can be estimated by an isotope mass balance calculation:

$$
\delta^{13} \mathrm{C}-\mathrm{MPA}=\frac{\left(\delta^{13} \mathrm{C}-\mathrm{MP}\right)-(1-\mathrm{F}) \delta^{13} \mathrm{C}-\mathrm{MPC}}{\mathrm{F}},
$$

where $\mathrm{F}$ denotes the fraction of methane derived from acetate (Figure $4 \mathrm{~b}$ ). The large range in $\delta^{13} \mathrm{C}$-MPC values, due to uncertainty in the isotope fractionation factor for $\mathrm{CO}_{2}$ reduction, limits the accuracy of the $\delta^{13} \mathrm{C}$-MPA calculation. It is possible, however, to place constraints on the isotopic composition of the methane produced by acetate fermentation. In the following section, we estimate $\delta^{13} \mathrm{C}-\mathrm{MPA}$ for two periods during the experiment: (1) the 51 to 58 day interval corresponding to minimum $\delta^{13} \mathrm{C}$-MP values and (2) the 86 to 93 day interval corresponding to maximum $\delta^{13} \mathrm{C}$-MP values.

During the 51 to 58 day interval, the methane produced by the sediment microcosm was depleted in ${ }^{13} \mathrm{C}\left(\delta^{13} \mathrm{C}-\mathrm{MP}=-94 \%\right.$ compared to the methane produced from $\mathrm{CO}_{2}\left(\delta^{13} \mathrm{C}-\mathrm{MPC}>-83 \%\right.$ ) (Figure 7). This implies a source of ${ }^{13} \mathrm{C}$-depleted methane derived from a pathway other than $\mathrm{CO}_{2}$ reduction. Acetate fermentation is the most likely source of this methane; the lack of methane production in the presence of sulfate argues against significant methane production from noncompetitive substrates. Acetate fermentation accounted for $34 \%$ of the methane produced at 58 days (Figure 4 b). Isotope mass balance (equation (11)) requires that the methane produced by acetate fermentation during the 51 to 58 day interval have a $\delta^{13} \mathrm{C}$ value less than $-115 \%$. This extreme level of ${ }^{13} \mathrm{C}$ depletion is only possible if the methyl group of the acetate molecule is highly depleted.

Net acetate accumulation during the 51 to 58 day interval (Figure $2 b$ ) indicates that gross production exceeded consumption. Since acetoclastic methanogens were not substrate limited, isotopic fractionation of the acetate methyl carbon was not influenced by closed system effects. Under these conditions, the 
carbon isotopic composition of the acetate methyl group $\left(\delta^{13} \mathrm{C}^{-}{ }^{*} \mathrm{CH}_{3} \mathrm{COOH}\right)$ can be calculated by rearranging an equation analogous to (10):

$$
\begin{aligned}
& \delta^{13} \mathrm{C}-{ }^{*} \mathrm{CH}_{3} \mathrm{COOH}= \\
& \quad \delta^{13} \mathrm{C}-\mathrm{MPA} \alpha_{\mathrm{AF}}+\left(\alpha_{\mathrm{AF}}-1\right) 10^{3},
\end{aligned}
$$

where $\alpha_{\mathrm{AF}}$ is the isotope fractionation factor for acetate dissimilation. Laboratory estimates of $\alpha_{\mathrm{AF}}$ range from 1.02 to 1.03 for pure cultures of the acetate-utilizing methanogen Methanosarcina barkeri [Risatti and Hayes, 1983; Krzycki et al., 1987]. Comparable values $(1.032 \pm 0.014)$ were estimated for methanogenic sediments from Cape Lookout Bight [Blair and Carter, 1992]. The latter values, inferred from measured downcore shifts in the isotopic composition of the acetate methyl carbon, are adopted for the following calculations. Given a $\delta^{13} \mathrm{C}$-MPA of $-115 \%$ for the 51 to 58 day interval (from equation (11)), we calculate a $\delta^{13} \mathrm{C}$ of the acetate methyl carbon of -74 to $-99 \%$ (equation (12)). The large range in the $\delta^{13} \mathrm{C}_{-}^{*} \mathrm{CH}_{3} \mathrm{COOH}$ values stems from uncertainty in $\alpha_{\mathrm{AF}}$.

Autotrophic acetogenic bacteria provide a mechanism for producing acetate with a methyl group that is highly depleted in ${ }^{13} \mathrm{C}$. Gelwicks et al. [1989] have shown that pure cultures of Acetobacterium woodii grown autotrophically on $\mathrm{CO}_{2}$ and $\mathrm{H}_{2}$ produce isotopically homogeneous acetate that is depleted in ${ }^{13} \mathrm{C}$ by $59 \%$ relative to the $\Sigma \mathrm{CO}_{2}$ pool. If the fractionation factor for Acetobacterium woodii in pure culture is applicable to microbial populations in the sediment microcosm, autotrophic acetogenesis during the 51 to 58 day interval would produce acetate with a methyl $\delta^{13} \mathrm{C}$ value of $-71 \%$. Although this $\delta^{13} \mathrm{C}^{*}{ }^{*} \mathrm{CH}_{3} \mathrm{COOH}$ value is slightly outside the range predicted above, it demonstrates the plausibility of extreme ${ }^{13} \mathrm{C}$ depletion in methane derived from autotrophically produced acetate.

At 86 days, acetate fermentation accounted for $87 \%$ of the methane produced by the sediment microcosm (Figure 4b). The methane produced during the 86 to 93 day interval was enriched in ${ }^{13} \mathrm{C}$ $\left(\delta^{13} \mathrm{C}-\mathrm{MP}=-42 \%\right.$ ) compared to the methane derived from $\mathrm{CO}_{2}$ reduction $\left({ }^{13} \mathrm{C}-\mathrm{MPC}<-62 \%\right)$ (Figure 7). Isotope mass balance constraints indicate that methane produced by acetate fermentation during this period had a $\delta^{13} \mathrm{C}$ value of -37 to $-39 \%$ (equation (11)).

The acetate pool was nearly quantitatively consumed during the 86 to 93 day interval (Figure 2a).
Assuming no isotopic fractionation during methyl group oxidation [Blair and Carter, 1992], the relationship between $\delta^{13} \mathrm{C}_{-}{ }^{*} \mathrm{CH}_{3} \mathrm{COOH}$ and $\delta^{13} \mathrm{C}$-MPA is given by a closed-system Raleigh equation [Hayes, 1983]:

$$
\begin{aligned}
& \delta^{13} \mathrm{C}^{*} \mathrm{CH}_{3} \mathrm{COOH}= \\
& \delta^{13} \mathrm{C}-\mathrm{MPA}-\frac{\left(\alpha_{\mathrm{AF}}-1\right)(1-f)}{\alpha_{\mathrm{AF}} f}[\ln (1-f)] 10^{3},
\end{aligned}
$$

where $f$ is the fraction of the acetate methyl carbon pool converted to methane. The $f$ value $(0.80)$ was calculated from the rate of methane production from acetate at 86 days (Figure $3 \mathrm{~b}$ ) divided by the net acetate depletion rate during the 86 to 93 day interval (Figure 2b). From (13), we calculate $\delta^{13} \mathrm{C}$ -

${ }^{*} \mathrm{CH}_{3} \mathrm{COOH}$ values ranging from -24 to $-33 \%$. Although the range of calculated values is large (reflecting uncertainty in $\alpha_{\mathrm{AF}}$ ), they overlap with values expected for acetate produced by fermentative processes $(-21$ to $-25 \%$ o [Blair and Carter, 1992].

The $\delta^{13} \mathrm{C}$ of methane produced from acetate (calculated by isotope mass balance, equation (11)) varied from less than $-115 \%$ ( 51 to 58 day interval) to greater than $-39 \%$ ( 86 to 93 day interval). Such large variations cannot be accounted for by changes in the isotope fractionation factor for acetate dissimilation. Rather, the variations in $\delta^{13} \mathrm{C}$-MPA imply changes in the isotopic composition of the acetate methyl carbon.

\section{Microbial Controls on $\mathrm{\delta}^{33} \mathrm{C}-\mathrm{CH}_{4}$}

We have shown that large variations in the $\delta^{13} \mathrm{C}$ of methane produced by the sediment microcosm were driven by shifts in the relative rates of $\mathrm{CO}_{2}$ reduction and acetate fermentation, as well as changes in the isotopic composition of the $\mathrm{CO}_{2}$ pool and the acetate methyl carbon. In this section, we present a scenario describing the microbial processes that may have played a role in controlling the variations in isotopic composition of methane produced by the microcosm.

Organic matter degradation in the sediment microcosm can be divided into three distinct periods: (1) the sulfate reduction period, (2) the sulfatemethane transition period, and (3) the methane production period. During the sulfate reduction period ( 0 to 42 days), high sulfate reduction rates (Figure 3a) were supported by rapid degradation of relatively fresh organic matter. Sulfate concentrations (Figure 2a) throughout this period exceeded the level 
at which sulfate-reducing bacteria become sulfatelimited (0.2 mM) [Ingvorsen et al., 1984]. In the presence of nonlimiting sulfate concentrations, sulfate-reducing bacteria maintain acetate and $\mathrm{H}_{2}$ concentrations at a level too low to support growth of methanogenic bacteria [Lovley et al., 1982; Lovley and Klug, 1986]. The acetate and $\mathrm{H}_{2}$ produced by organic matter degradation were essentially unavailable to methanogenic bacteria and total methane production rates were negligible (Figure 4a).

During the sulfate-methane transition period (42 to 60 days), sulfate concentrations dropped to threshold levels for uptake by sulfate-reducing bacteria (10 to $20 \mu \mathrm{M})$ [Ingvorsen et al., 1984]. Methane began to accumulate in the magnum syringe (Figure 2a), suggesting that methanogens had replaced sulfate reducers as the primary acetate and $\mathrm{H}_{2}$ consumers. Methane production was initially dominated by $\mathrm{CO}_{2}$ reduction (Figure $3 \mathrm{~b}$ ), possibly because methanogens growing on $\mathrm{H}_{2}-\mathrm{CO}_{2}$ have faster doubling times than acetoclastic species [Vogels et al., 1988]. The first methane produced by the microcosm had a $\delta^{13} \mathrm{C}$ of $-80 \%$, within the range of values expected for methane produced from $\mathrm{CO}_{2}$ (Figure 7).

The accumulation of acetate during the sulfatemethane transition period (Figure $2 b$ ) suggests that the existing population of acetate-utilizing methanogenic bacteria was unable to keep pace with acetate production. It is not known whether the $\mathrm{H}_{2}$ reservoir experienced a similar accumulation, but relatively slow rates of $\mathrm{CO}_{2}$ reduction during the sulfatemethane transition (Figure $3 \mathrm{~b}$ ) suggest that the population of methanogenic bacteria was not fully developed. These conditions would be favorable for $\mathrm{H}_{2}$-consuming acetogenic bacteria that normally cannot compete with sulfate-reducing or methanogenic bacteria [Lovley and Klug, 1983]. Most acetogenic bacteria capable of growing on $\mathrm{H}_{2}-\mathrm{CO}_{2}$ are also able to grow by fermenting sugars to acetate [Dolfing, 1988]. Therefore acetogenic bacteria (unlike methanogens) can exist in a commensal relationship with sulfate-reducing bacteria, and would be well poised to take advantage of a temporary reduction in $\mathrm{H}_{2}$ demand that might follow sulfate depletion. Acetate produced from $\mathrm{H}_{2}-\mathrm{CO}_{2}$ by autotrophic acetogenic bacteria would be highly depleted in ${ }^{13} \mathrm{C}$ [Gelwicks et al., 1989]. Subsequent methane production from this acetate could account for the ${ }^{13} \mathrm{C}$-depleted methane $(-94 \%$ ) produced at the end of the transition period (Figure 7).
The methane production period (60 to 114 days) can be divided into two subperiods. During the first subperiod ( 60 to 90 days), methane production was dominated by acetate fermentation (Figure $3 b$ ). The high methane production rates were fueled by the large acetate pool that had begun accumulating during the sulfate-methane transition (Figure 2b). Methane production rates from $\mathrm{CO}_{2}$ reached a plateau during this subperiod (Figure $3 \mathrm{~b}$ ), suggesting that $\mathrm{H}_{2}$ consuming methanogens were keeping pace with $\mathrm{H}_{2}$ production. Since acetogens cannot successfully compete for $\mathrm{H}_{2}$ with a well-developed methanogen population [Lovley and Klug, 1983], the acetate that accumulated throughout most of this subperiod was probably synthesized via the sugar fermentation pathway. The methyl carbon in acetate produced by sugar fermentation would be isotopically "heavy," and thus give rise to methane enriched in ${ }^{13} \mathrm{C}$ [Whiticar et al., 1986]. The ${ }^{13} \mathrm{C}$-rich methane $(-42 \%)$ produced toward the end of the initial methane production subperiod (Figure 7) is consistent with the predominance of methane production from acetate synthesized by the fermentative pathway.

The second methane production subperiod ( 90 to 114 days) marks the return to a stable microcosm. Acetate concentrations were depleted to steady state levels (Figure 2b) and total methane production rates decreased gradually (Figure $4 \mathrm{a}$ ) as the abundance of labile organic matter declined. Assuming that methanogens were the exclusive acetate and $\mathrm{H}_{2}$ sinks during this period, the relative availability of acetate and $\mathrm{H}_{2}$ must have been controlled by their respective production rates. Methane production was dominated by $\mathrm{CO}_{2}$ reduction (Figure 3 b), suggesting that $\mathrm{H}_{2}$ was produced in stoichiometric excess of acetate.

The methane produced during the final subperiod was enriched in ${ }^{13} \mathrm{C}(-46$ to $-60 \%$ ) relative to the methane produced during the sulfate-methane transition ( -80 to $-94 \%$ ). Although $\mathrm{CO}_{2}$ reduction accounted for $-70 \%$ of the methane produced during both these periods (Figure $4 \mathrm{~b}$ ), the methane precursors were enriched in ${ }^{13} \mathrm{C}$ during the latter period. The $\Sigma \mathrm{CO}_{2}$ pool was progressively enriched in ${ }^{13} \mathrm{C}$ following sulfate depletion (Figure $5 \mathrm{a}$ ), presumably due to preferential uptake of ${ }^{12} \mathrm{CO}_{2}$ by methanogenic and possibly autotrophic acetogenic bacteria. The ${ }^{13} \mathrm{C}$ enrichment in the acetate methyl group may be related to changes in the pathway of acetate synthesis (i.e., autotrophic acetogenesis during the sulfatemethane transition; sugar fermentation during the methane production period). 
Comparison of Laboratory Microcosm and Natural Sediment

A laboratory microcosm is a highly artificial system. Removing sediment from its natural setting and placing it in a sealed container will inevitably lead to perturbations. The results of the microcosm experiment must be compared with in situ data to evaluate whether the processes that control isotopic variability in the sediment microcosm may also operate in undisturbed marine sediment.

The stable carbon isotopic composition of methane contained in gas bubbles emitted from Cape Lookout Bight sediments (Figure 8a) varies by $\sim 10 \%$ over the course of a year [Martens et al., 1986; Burke et al., 1987]. Between February and May, $\delta^{13} \mathrm{C}_{-} \mathrm{CH}_{4}$ values remain relatively constant at -63 to $-65 \%$. For a short period at the end of May, $\delta^{13} \mathrm{C}_{-} \mathrm{CH}_{4}$ values drop to $-68.5 \%$. The transient decline is followed by a shift toward more positive $\delta^{13} \mathrm{C}$ values that continues through the middle of August. Between August and November, $\delta^{13} \mathrm{C}_{-} \mathrm{CH}_{4}$ values gradually decline from -57 to $-62 \%$. Martens et al. [1986, p. 1300] hypothesize that the "observed seasonal isotopic variations are ... controlled by changes in pathways of methane production and cycling of acetate and molecular hydrogen within the sediments".

There is a dramatic increase in the acetate inventory in Cape Lookout Bight sediments between May and August (Figure 8b). The bulk of the summertime acetate inventory is contained in a narrow subsurface peak centered at 10 to $15 \mathrm{~cm}$ [Sansone and Martens, 1982]. The vertical extent of the sulfate reduction zone in Cape Lookout Bight decreases during the spring, as sulfate reduction rates increase in response to higher sediment temperatures [Crill and Martens, 1987]. The appearance of the subsurface acetate peak at the end of May corresponds to the sulfatedepletion depth crossing the $15 \mathrm{~cm}$ horizon [Sansone and Martens, 1982].

Sediment accumulation rates for Cape Lookout Bight (determined from ${ }^{7} \mathrm{Be}$ inventories) indicate that sediment residing at the 10 to $15 \mathrm{~cm}$ interval in May was deposited at the sediment surface during the late fall [Canuel et al., 1990]. As a result of relatively cool sediment temperatures, organic matter deposited in the fall is effectively preserved through the winter and spring, reaching the 10 to $15 \mathrm{~cm}$ horizon with a large fraction of its labile component intact. As sediments warm during the spring, this labile material is able to support high rates of acetate production.
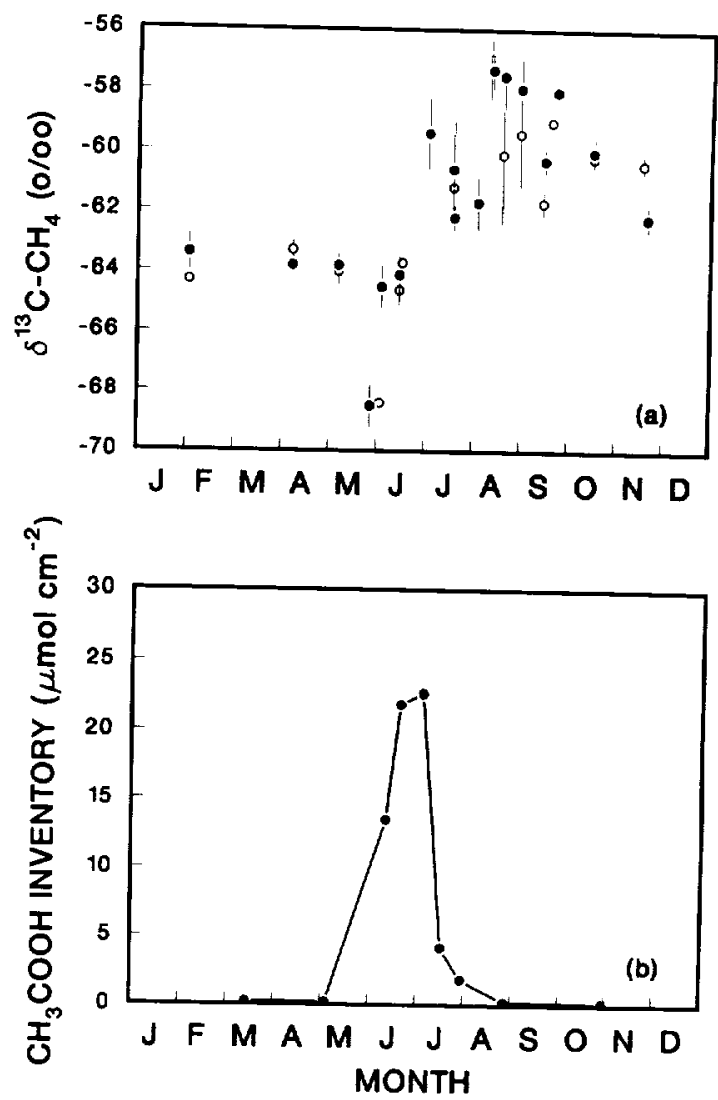

Fig. 8. Seasonal changes in Cape Lookout Bight sediment. (a) $\delta^{13} \mathrm{C}$ of methane in gas bubbles collected during 1983 to 1984 (open circles denote data from Martens et al. [1986]; closed circles denote data from Burke et al. [1987]); (b) acetate inventory calculated by integrating acetate concentration-depth distributions ( 0 to $36 \mathrm{~cm}$ ) determined on sediment cores collected in 1990. The error bars in Figure 8a denote the standard deviation based on two to four replicate samples.

The processes that lead to rapid acetate accumulation in the sediment column (Figure $8 \mathrm{~b}$ ) and the sediment microcosm (Figure $2 b$ ) are presumably similar: high rates of acetate production accompanied by a sudden reduction in the rate of acetate consumption. In the case of the sediment microcosm, the decline in acetate consumption appears to be caused by the cessation of sulfate reduction (due to sulfatelimitation) and a lag in acetate consumption by methanogenic bacteria (due the slow growth rate of acetoclastic methanogens).

There is a striking similarity in the relationship between $\delta^{13} \mathrm{C}-\mathrm{CH}_{4}$ and acetate concentration (or inventory) for both the microcosm and the undis- 
turbed sediment (cf. Figures 2b, 7, and 8). For both systems, methane produced (or emitted) at the beginning of the acetate accumulation period is relatively depleted in ${ }^{13} \mathrm{C}$. Likewise, methane produced (or emitted) during the period of rapid acetate depletion is relatively enriched in ${ }^{13} \mathrm{C}$. Seasonal variations in $\delta^{13} \mathrm{C}_{-}-\mathrm{CH}_{4}(\sim 10 \%)$ are much smaller than variations in the microcosm $(\sim 50 \%)$, presumably due to inertia imposed by the sediment column methane inventory.

The similarities between laboratory and field data suggest that similar processes control the isotopic composition of methane produced by the laboratory microcosm and natural sediment. The shoaling of the sulfate-depletion depth to the sediment horizon containing labile organic material may initiate a scenario similar to that described for the sediment microcosm. First, sulfate depletion may lead to a temporary reduction in competition for acetate and $\mathrm{H}_{2}$, resulting in acetate pooling and possibly, production of ${ }^{13} \mathrm{C}$ depleted acetate by autotrophic acetogenic bacteria. The ${ }^{13} \mathrm{C}$-depleted methane emitted at the end of May is consistent with a predominance of the $\mathrm{CO}_{2}$ reduction pathway (due to the slow growth rate of acetoclastic methanogens) and possibly, methane production from ${ }^{13} \mathrm{C}$-depleted acetate. Second, acetate fermentation may become the dominant methane production pathway as the acetoclastic methanogens respond to the elevated acetate concentrations. Since acetogens cannot compete for $\mathrm{H}_{2}$ with an active methanogen population, autotrophic acetogenesis is unlikely. The ${ }^{13} \mathrm{C}$-rich methane emitted from June thru August is consistent with acetate dissimilation being the dominant methane production pathway. Third, the methane production pathway may shift in favor of $\mathrm{CO}_{2}$ reduction after the acetate inventory is fully depleted. The shift toward ${ }^{13} \mathrm{C}$ depleted methane from September thru November is consistent with increased importance of $\mathrm{CO}_{2}$ reduction after depletion of the acetate reservoir.

\section{CONCLUSIONS}

The laboratory microcosm experiment demonstrates that a single sample of anoxic marine sediment incubated at constant temperature can produce methane with $\delta^{13} \mathrm{C}$ values that vary from -94 to $-42 \%$. The variations in $\delta^{13} \mathrm{C}-\mathrm{CH}_{4}$ were caused by changes in the relative importance of acetate fermentation and $\mathrm{CO}_{2}$ reduction, as well as changes in the isotopic composition of the methane precursors (acetate and $\mathrm{CO}_{2}$ ). Concurrent methane oxidation and production were observed, but oxidation was a small fraction $(2.4 \%)$ of the gross production. It is unlikely that methane oxidation was an important factor in controlling the isotopic composition of methane.

Variations in the relative importance of $\mathrm{CO}_{2}$ reduction and acetate fermentation can be understood in terms of changes in microbial processes that occurred as sediment bacteria responded to sulfate depletion. The initial predominance of the $\mathrm{CO}_{2}$ reduction pathway is consistent with the relatively slow growth rate of acetate-utilizing methanogens. The subsequent shift in pathway to acetate fermentation appears to be a response to the elevated acetate concentrations that had accumulated following sulfate depletion. The return to $\mathrm{CO}_{2}$ reduction as the dominant pathway toward the end of the microcosm experiment corresponds with the rapid and nearly quantitative depletion of the acetate pool.

The apparent changes in the isotopic composition of the acetate methyl carbon may be related to changes in the pathway of acetate synthesis, which in turn, were controlled by competition for $\mathrm{H}_{2}$. Changes in isotopic composition of the $\mathrm{\Sigma CO}_{2}$ pool during the microcosm experiment are presumably due to isotopic fractionation associated with $\mathrm{CO}_{2}$ reduction by methanogenic and possibly autotrophic acetogenic bacteria.

A comparison of microcosm and field data reveals a striking similarity in the relationship between $\delta^{13} \mathrm{C}_{-} \mathrm{CH}_{4}$ and acetate concentration or inventory. This suggests that the processes that control in situ seasonal variations in the isotopic composition of methane emitted from Cape Lookout Bight sediments may be similar to those that controlled variations in the isotopic composition of methane produced by the sediment microcosm. This experiment demonstrates that laboratory-based process studies coupled with field measurements provide a powerful tool for interpreting and understanding stable isotope signatures in nature.

Acknowledgments. This work was supported by Technical Service contract OD4067NTEX from the Environmental Protection Agency (MJA) and grant OCE-9017979 from the National Science Foundation (CSM, DBA, MJA). Additional support was supplied by grant NAGW-838 from the National Aeronautics and Space Administration (NEB). We are grateful to David Meece for his thoughtful review of an earlier version of this paper. Some of the mathematical treatments presented in this paper benefited from discussions with Richard McCaffrey. 
Stable carbon isotope analyses were done by Howard Mendlovitz, Julie Gunn, and Connie Crossley. The authors wish to thank Ken Sandbeck and Bill Reeburgh for supplying the ${ }^{14} \mathrm{CH}_{4}$. We also wish to thank two anonymous reviewers for their constructive comments.

\section{REFERENCES}

Ahlberg, J., E. Nilson, and J. Walsh, The Theory of Splines and Their Applications, Academic, San Diego, Calif., 1967.

Albert, D. B., C. Taylor, and C. S. Martens, Sulfate reduction rates and low molecular weight fatty acid concentrations in the water column and surficial sediments of the Black Sea, Deep Sea Res., in press, 1992.

Alperin, M. J., and W. S. Reeburgh, Inhibition experiments on anaerobic methane oxidation, Appl. Environ. Microbiol., 50, 940-945, 1985.

Alperin, M. J., W. S. Reeburgh, and M. J. Whiticar, Carbon and hydrogen isotope fractionation resulting from anaerobic methane oxidation, Global Biogeochem. Cycles, 2, 279288, 1988.

Bernard, B. B., J. M. Brooks, and W. M. Sackett, Natural gas seepage in the Gulf of Mexico, Earth Planet. Sci. Lett., 31, 48-54, 1976.

Blair, N. E., and W. D. Carter, The carbon isotope biogeochemistry of acetate from a methanogenic marine sediment, Geochim. Cosmochim. Acta, 56, 1247-1258, 1992.

Blair, N. E., C. S. Martens, and D. J. Des Marais, Natural abundances of carbon isotopes in acetate from a coastal marine sediment, Science, 236, 66-68, 1987.

Blair, N. E., S. E. Boehme, and W. D. Carter, The carbon isotope biogeochemistry of methane production in anoxic sediments. 1. A field study, in The Biogeochemistry of Global Change: Radiative Trace Gases, edited by R. S. Oremland, Chapman and Hall, London, in press, 1992.

Blake, D. R., and F. S. Rowland, Continuing worldwide increase in tropospheric methane, 1978 to 1987, Science, 239, 1129-1131, 1988.

Bottinga, Y., Calculated fractionation factors for carbon and hydrogen isotope exchange in the system calcite-carbon dioxide-graphite-methanehydrogen-water vapor, Geochim. Cosmochim. Acta, 33, 49-64, 1969.

Burke, R. A., Jr., C. S. Martens, and W. M. Sackett, Seasonal variations in the D/H and
${ }^{13} \mathrm{C}{ }^{12} \mathrm{C}$ ratios of microbial methane in surface sediments, Nature, 332, 829-831, 1987.

Canuel, E. A., C. S. Martens, and L. K. Benninger, Seasonal variations in ${ }^{7} \mathrm{Be}$ activity in the sediments of Cape Lookout Bight, North Carolina Geochim. Cosmochim. Acta, 54, 237-245, 1990.

Chanton, J. P., and C. S. Martens, Seasonal variations in ebullitive flux and carbon isotopic composition of methane in a tidal freshwater estuary, Global Biogeochem. Cycles, 2, 289-298, 1988.

Chanton, J. P., C. S. Martens, and G. W. Kipphut, Lead-210 sediment geochronology in a changing coastal environment, Geochim. Cosmochim. Acta, 47, 1791-1804, 1983.

Cicerone, R. J., and R. S. Oremland, Biogeochemical aspects of atmospheric chemistry, Global Biogeochem. Cycles, 2, 299-327, 1988.

Craig, H., Isotopic standards for carbon and oxygen and correction factors for mass-spectrometric analysis of carbon dioxide, Geochim. Cosmochim. Acta, 12, 133-149, 1957.

Crill, P. M., and C. S. Martens, Methane production from bicarbonate and acetate in anoxic marine sediment, Geochim. Cosmochim. Acta, 50, 2089. 2097, 1986.

Crill, P. M., and C. S. Martens, Biogeochemical cycling in an organic-rich coastal marine basin. 6 . Temporal and spatial variations in sulfate reduction rates, Geochim. Cosmochim. Acta, 51, 1175-1186, 1987.

Deuser, W. G., and E. T. Degens, Carbon isotope fractionation in the system $\mathrm{CO}_{2}$ (gas)$\mathrm{CO}_{2}$ (aqueous)- $\mathrm{HCO}_{3}{ }^{-}$(aqueous), Nature, 215 , 1033-1035, 1967.

Dolfing, J., Acetogenesis, in Biology of Anaerobic Microorganisms, edited by A. J. B. Zehnder, pp. 417-468, John Wiley, New York, 1988.

Fuchs, G., R. Thauer, H. Ziegler, and W. Stichler, Carbon isotope fractionation by Methanobacterium thermoautotrophicum, Arch. Microbiol., 120, 135-139, 1979.

Fung, I., J. John, J. Lerner, E. Matthews, M. Prather, L. P. Steele, and P. J. Steele, Threedimensional model synthesis of the global methane cycle, J. Geophys. Res., 96, 13,033$13,065,1991$.

Games, L. M., and J. M. Hayes, On the mechanisms of $\mathrm{CO}_{2}$ and $\mathrm{CH}_{4}$ production in natural anaerobic environments, in Environmental Biogeochemistry, edited by J. O. Nriagu, pp. 5173, Science, New York, 1976. 
Gelwicks, J. T., J. Bruno Risatti, and J. M. Hayes, Carbon isotope effects associated with autotrophic acetogenesis, Org. Geochem., 14, 441-446, 1989.

Halsted, R. E., and A. O. Nier, Gas flow through the mass spectrometer viscous leak, Rev. Sci. Instrum., 21, 1019-1021, 1950.

Hayes, J. M., Practice and principles of isotopic measurements in organic chemistry, in Organic Geochemistry of Contemporaneous and Ancient Sediments, edited by W. G. Meinschein, pp. 5-1 5-31, Society of Economic Paleotologists and Mineralogists, Tulsa, Okla., 1983.

Hayes, J. M., D. J. Des Marais, D. W. Peterson, D. A. Schoeller, and S. P. Taylor, High precision stable isotope ratios from microgram samples, in Advances in Mass Spectrometry, vol. 7, edited by N. R. Daly, pp. 475-480, Heydon and Son, London, 1977.

Ingvorsen, K., A. J. B. Zehnder, and B. B. Jørgensen, Kinetics of sulfate and acetate uptake by Desulfovibrio postgatei, Appl. Environ. Microbiol., 47, 403-408, 1984.

Jørgensen, B. B., A comparison of the methods for the quantification of bacterial sulfate reduction in coastal marine sediments. I. Measurement with radiotracer techniques, Geomicrobiol. J., 1, 1127, 1978.

King, G. M., Methanogenesis from methylated amines in a hypersaline algal mat, Appl. Environ. Microbiol., 54, 130-136, 1988.

King, G. M., M. J. Klug, and D. R. Lovley, Metabolism of acetate, methanol, and methylated amines in intertidal sediments of Lowes Cove, Maine, Appl. Environ. Microbiol., 45, 18451853, 1983.

King, S. L., P. D. Quay, and J. M. Lansdown, The ${ }^{13} \mathrm{C} /{ }^{12} \mathrm{C}$ kinetic isotope effect for soil oxidation of methane at ambient atmospheric concentrations, $J$. Geophys. Res., 94, 18,273-18,277, 1989.

Klump, J. V., and C. S. Martens, The seasonality of nutrient regeneration in an organic-rich coastal sediment: Kinetic modeling of changing porewater nutrient and sulfate distributions, Limnol. Oceanogr., 34, 559-577, 1989.

Kristjansson, J. K., P. Schonheit, and R. K. Thauer, Different $K_{s}$ values for hydrogen of methanogenic bacteria and sulfate-reducing bacteria: An explanation for the apparent inhibition of methanogenesis by sulfate, Arch. Microbiol., $131,278-282,1982$.
Krzycki, D. R., W. R. Kenealy, M. J. DeNiro, and J. G. Zeikus, Stable carbon isotope fractionation by Methanosarcina barkeri during methanogenesis from acetate, methanol, or carbon dioxidehydrogen, Appl. Environ. Microbiol., 53, 25972599, 1987.

Lovley, D. R., and M. J. Klug, Methanogenesis from methanol and methylated amines and acetogenesis from hydrogen and carbon dioxide in the sediments of a eutrophic lake, Appl. Environ. Microbiol., 45, 1310-1315, 1983.

Lovley, D. R., and M. J. Klug, Model for the distribution of sulfate reduction and methanogenesis in freshwater sediments, Geochim. Cosmochim. Acta, 50, 11-18, 1986.

Lovley, D. R., D. F. Dwyer, and M. J. Klug, Kinetic analysis of competition between sulfate reducers and methanogens for hydrogen in sediments, Appl. Environ. Microbiol., 43, 13731379, 1982.

Martens, C. S., and J. V. Klump, Biogeochemical cycling in an organic-rich coastal marine basin. 1 . Methane sediment-water exchange processes, Geochim. Cosmochim. Acta, 44, 471-490, 1980.

Martens, C. S., and J. V. Klump, Biogeochemical cycling in an organic-rich coastal marine basin. 4 . An organic carbon budget for sediments dominated by sulfate reduction and methanogenesis. Geochim. Cosmochim Acta, 48, 1987-2004, 1984.

Martens, C. S., N. E. Blair, C. D. Green, and D. J. Des Marais, Seasonal variations in the stable carbon isotopic signature of biogenic methane in a coastal sediment, Science, 233, 1300-1303, 1986.

Martens, C. S., R. I. Haddad, and J. P. Chanton, Organic matter accumulation, remineralization and burial in an anoxic coastal sediment, in Productivity, Accumulation, and Preservation of Organic Matter: Recent and Ancient Sediments, edited by J. K. Whelan and J. W. Farrington, pp. 82-98, Columbia University Press, New York, 1992.

Mason, E. A., and R. B. Evans III, Graham's law: Simple demonstrations of gases in motion, Part 1 , Theory, J. Chem. Ed., 46, 358-364, 1969.

Mason, E. A., and B. Kronstadt, Graham's laws of diffusion and effusion, J. Chem. Ed., 44, 740744, 1967.

Oremland, R. S., The hiogeochemistry of methanogenic bacteria, in Biology of Anaerobic Microorganisms, edited by A. J. B. Zehnder, pp. 641-705, John Wiley, New York, 1988. 
Oremland, R. S., L. M. Marsh, and S. Polcin, Methane production and simultaneous sulfate reduction in anoxic saltmarsh sediments, Nature, 296, 143-145, 1982.

Pearman, G. I., D. Etheridge, F. de Silva, and P. J. Fraser, Evidence of changing concentrations of atmospheric $\mathrm{CO}_{2}, \mathrm{~N}_{2} \mathrm{O}$, and $\mathrm{CH}_{4}$ from air bubbles in Antarctic ice, Nature, 320, 248-250, 1986.

Prinn, R., D. Cunnold, R. Rasmussen, P. Simmonds, F. Alyea, A. Crawford, P. Fraser, and R. Rosen, Atmospheric trends in methylchloroform and the global average for the hydroxyl radical, Science, 238, 945-950, 1987.

Quay, P. D., S. L. King, J. M. Lansdown, and D. O. Wilbur, Isotopic composition of methane released from wetlands: Implications for the increase in atmospheric methane, Global Biogeochem. Cycles, 2, 385-397, 1988.

Quay, P. D., S. L. King, J. Stutsman, D. O. Wilbur, L. P. Stecle, I. Fung, R. H. Gammon, T. A. Brown, G. W. Farwell, P. M. Grootes, and F. H. Schmidt, Carbon isotopic composition of atmospheric $\mathrm{CH}_{4}$ : Fossil and biomass burning source strengths, Global Biogeochem. Cycles, 5, 25-47, 1991.

Rees, C. E., A steady-state model for sulphur isotope fractionation in bacterial reduction processes, Geochim. Cosmochim. Acta, 37, 1141-1162, 1973.

Risatti, J. B., and J. M. Hayes, Bingenic acetate and the origin of sedimentary biogenic methane, Geol. Soc. Am. Abstr. Prog., 15, 671, 1983.

Sansone F. J., and C. S. Martens, Volatile fatty acid cycling in organic-rich marine sediments, Geochim. Cosmochim. Acta, 46, 1575-1589. 1982.

Schaff, T., L. Levin, N. Blair, D. Demaster, R. Pope, and S. Bochme, Spatial heterogeneity of benthos on North Carolina continental slope; large $(100 \mathrm{~km})$-scale variation, Mar. Ecol. Prog. Ser., in press, 1992.

Schonheit, P., J. K. Kristjansson, and R. K. Thauer, Kinetic mechanism for the ability of sulfate reducers to out-compete methanogens for acetate, Arch. Microbiol., 132, 285-288, 1982.

Stern, M. J., and P. C. Vogel, Relative ${ }^{14} \mathrm{C}-{ }^{13} \mathrm{C}$ kinetic isotope effects, J. Chem. Phys., 55, 20072013, 1971.

Stevens, C. M., and A. Engelkemeir, Stable carbon isotopic composition of methane from some natural and anthropogenic sources, J. Geophys. Res., 93, 725-733, 1988.
Strayer, R. F., and J. M. Tiedje, Kinetic parameters of the conversion of methane precursors to methane in hypercutrophic lake sediment, $\mathrm{Appl}$. Environ. Microbiol., 36, 330-340, 1978.

Stumm, W., and J. J. Morgan, Aquatic Chemistry, 2nd ed., John Wiley, New York, 1981.

Taylor, J. A., G. P. Brasseur, P. R. Zimmerman, and R. J. Cicerone, A study of the sources and sinks of methane and methyl chloroform using a global three-dimensional Lagrangian tropospheric tracer transport model, J. Geophys. Res., 96, 3013-3044, 1991.

Tyler, S. C., The global methane budget, in Microbial Production and Consumption of Greenhouse Gases: Methane, Nitrogen Oxides, and Halomethanes, edited by J. E. Rogers and W. B. Whitman, pp. 7-38, American Society for Microbiology, Washington, D. C., 1991.

Tyler, S. C., P. R. Zimmerman, C. Cumberbatch, J. P. Greenberg, C. Westberg, and J. P. E. C. Darlington, Measurements and interpretation of $\delta^{13} \mathrm{C}$ of methane from termites, rice paddies, and wetlands in Kenya, Global Biogeochem. Cycles, 2, 341-355, 1988.

Vaghjiani, G. L., and A. R. Ravishankara, New measurement of the rate coefficient for the reaction of $\mathrm{OH}$ with methane, Nature, 350, 406-409, 1991.

Vogels, G. D., K. T. Keltjens, and C. Van der Drift, Biochemistry of methane production, in Biology of Anaerobic Microorganisms, edited by A. J. B. Zehnder, pp. 707-770, John Wiley, New York, 1988.

Wahlen, M., N. Taneka, R. Henry, B. Deck, J. Zeglen, J. S. Vogel, J. Southon, A. Shemesi, R. Fairbanks, and W. Broccker, Carbon- 14 in methane sources and in atmospheric methane: The contribution from fossil carbon, Science, 245 . 286-290, 1989

Wendt, I., Fractionation of carbon isotopes and its temperature dependence in the system $\mathrm{CO}_{2}$-gas$\mathrm{CO}_{2}$ in solution and $\mathrm{HCO}_{3}-\mathrm{CO}_{2}$ in solution, Earth Planet. Sci. Lett., 4, 64-68, 1968.

Westrich, J. T., and R. A. Berner, The role of sedimentary organic matter in bacterial sulfate reduction: The G model tested, Limnol. Oceanogr., 29, 236-249, 1984.

Whiticar, M. J., E. Faber, and M. Schoell, Biogenic methane formation in marine and freshwater environments: $\mathrm{CO}_{2}$ reduction vs. acetate fermentation -- Isotope evidence, Geochim. Cosmochim. Acta, 50, 693-709, 1986. 
Yamamoto, S., J. B. Alcauskas, and T. E. Crozier, Solubility of methane in distilled water and seawater, J. Chem. Eng. Data, 21, 78-80, 1976.

D. B. Albert, M. J. Alperin, T. M. Hoehler, and C. S. Martens, Curriculum in Marine Sciences,
University of North Carolina, Chapel Hill, NC 27599-3300.

N. E. Blair, Department of Marine, Earth, and Atmospheric Sciences, North Carolina State University, Raleigh, NC 27695-8208.

(Received February 21, 1992; revised June 24, 1992;

accepted July 9, 1992.) 
- 